ISSN: 0213-2060

DOI: http://dx.doi.org/10.14201/shhme201533201232

\title{
RASGOS DE LA REFORMA DEL CLERO EN LA PENÍNSULA IBÉRICA DURANTE EL SIGLO XI ${ }^{1}$
}

\author{
Features of the Reform of the Clergy in the Iberian Peninsula during the $11^{\text {th }}$ \\ Century
}

José Antonio CALVO GÓMEZ

Instituto Español de Historia Eclesiástica. ROMA. I Depto. de Humanidades. Facultad de Ciencias Sociales y Jurídicas. Universidad Católica de Avila. C/ Canteros, s/n.E-05005 Ávila. C. e.: jantonio.calvo@ucavila.es

Recibido: 2014-06-03

Revisado: 2014-07-15

Aceptado: 2014-10-03

RESUMEN: Este artículo estudia la situación del clero de la Península Ibérica durante la Reforma Gregoriana, en el siglo XI. La existencia de las iglesias y monasterios propios, la injerencia laica en la provisión de los beneficios, y los clérigos nicolaítas y simoníacos exigieron la actuación decidida de los reformadores enviados directamente por el papa León IX (1049-1054) y por sus sucesores, en particular Alejandro II (1061-1073) y Gregorio VII (1073-1085), que dio nombre a la reforma. La peculiaridad hispánica de la reforma, imbuida durante siglos en la repoblación cristiana del territorio, exigió algunos de los instrumentos más importantes de este momento: los sínodos diocesanos, convocados y presididos por los legados pontificios, y la erección de comunidades de canónigos regulares, según la Regla de san Agustín.

Palabras clave: Reforma Gregoriana; Clero; Repoblación; Península Ibérica; Siglo XI.

ABSTRACT: This article examines the situation of the clergy of the Iberian Peninsula during the Gregorian Reform, in the $11^{\text {th }}$ Century. The existence of private churches and

1 Este trabajo ha sido realizado con la ayuda del Centro Español de Estudios Eclesiásticos, anejo a la Iglesia Nacional Española de Santiago y Montserrat en Roma, en el marco de los proyectos de investigación del curso 2013-2014. 
monasteries, secular interference in the provision of the benefits, and the nicolaitans and simoniac clerics demanded the determined actions of reformers sent directly by pope Leo IX (1049-1054) and his successors, in particular Alexander II (1061-1073) and Gregory VII (1073-1085), who nominated the reform. The Hispanic peculiarity of the reformation, imbued for centuries in the Christian repopulation of the territory, demanded some of the most important instruments of this time: the diocesan synods convened and presided over by the papal legates, and the erection of communities of regular canons, according to the Rule of Saint Augustine.

Keywords: Gregorian Reform; Clergy; Repopulation; Iberian Peninsula; $11^{\text {th }}$ Century.

SUMARIO: 0 Introducción. 1 La repoblación como clave de interpretación de la reforma. 2 Las iglesias propias en la Península en el siglo XI. 3 Los pecados del clero peninsular. 4 Los sínodos de reforma durante el siglo XI. 5 Conclusión. 6 Referencias bibliográficas.

\section{INTRODUCCIÓN}

La relación con los reinos hispánicos de los promotores de la Reforma Gregoriana, en general, y del papa Hildebrando (1073-1085), en particular, en la que se afrontó la renovación de la vida del clero y de las costumbres, así como la implantación de un nuevo derecho y del rito romano en detrimento del rito mozárabe o hispánico, entonces en franco retroceso, llevó acuñados los sellos de la reconquista y la repoblación.

La recuperación del antiguo solar visigodo condicionó poderosamente la actuación de los reformadores y la concepción del pontífice enlazó ambos empeños, que se materializó en las expediciones de la nobleza francesa dirigida por Ebuldo de Roucy y en la encomienda que recibió el cardenal Hugo Cándido cuando el papa Gregorio VII se disponía a acompañar la flota que salió en defensa de Bizancio, amenazado por los turcos. De acuerdo a este proyecto, el Islam se vería atacado simultáneamente en Oriente y Occidente, con lo que se lograría la unión con la Iglesia griega y el rescate de la plaza peninsular.

No hay razones de peso para separar la explicación sobre la necesidad de la reforma del clero de la Península Ibérica a mediados del siglo xi y la de cuantos elementos configuraron su deriva en este período histórico en el resto de la Europa Occidental ${ }^{2}$.

2 La situación del clero peninsular durante la Baja Edad Media, en general, y en la etapa gregoriana, en particular, ha ocupado a numerosos investigadores durante años. Además de los textos específicos que citamos abajo, vid. Garzón Pareja, Manuel. Diezmos y tributos del clero de Granada. Granada: Archivo de la Real Chancillería, 1974; Guijarro González, Susana. «Las escuelas y la formación del clero de las catedrales en las diócesis castellano-leonesas (siglos Xi al xv)». En Iglesia Duarte, José Ignacio de la (coord.). La enseñanza en la Edad Media. X Semana de Estudios Medievales de Nájera. Logrońo: Instituto de Estudios Riojanos, 2000, pp. 61-96; Martín Martín, José Luis. «El poder de los canónigos medievales». Historia 16, 1981, vol. 61, pp. 55- 60; Ídem. «El clero rural en la Corona de Castila». En Martínez San Pedro, María de los Desamparados y Segura del Pino, Dolores. La Iglesia en el mundo medieval y moderno. Almería: Instituto de Estudios Almerienses, 2004, pp. 55-82; ÍDEM. "Beneficios y oficios del clero rural castellano (siglos XIII-XV)». Anuario de Estudios Medievales, 2005, vol. 35, pp. 693-736; Nieto Soria, José Manuel y Sanz Sancho, Iluminado. La época medieval: Iglesia y cultura. Madrid: Istmo, 2001. 
De hecho, sin detenernos ahora en aquellos otros escenarios, los datos históricos parecen indicar la continuidad, más que la ruptura, con las circunstancias y penurias que se descubrieron más allá de los Pirineos.

Pero resulta verdaderamente ilustrativo atender a la peculiaridad del solar hispánico $^{3}$, imbuido durante ańos en la reconquista, o recuperación para la cristianitas del antiguo reino visigodo, que la historiografía contemporánea, desde afirmaciones de corte socioeconómico, expresó con rasgos de colonización-repoblación ${ }^{4}$, al tiempo que relegó a un segundo lugar el papel desempeńado por el elemento bélico más propio de la narración histórica de autores anteriores. Este tampoco es el lugar para afrontar el problema terminológico que suscitó este concepto y, en cualquier caso, su empleo en este trabajo es meramente aproximativo.

Al particularizar las discusiones que afrontaron los protagonistas de la Reforma Gregoriana, resultará más interesante recuperar la situación del sacerdocio hispánico bajomedieval, la duda que lanzó la historiografía contemporánea sobre las iglesias propias en este territorio y los mecanismos que ensayaron para impulsar aquí los proyectos emanados de la cátedra romana en su lucha contra los vicios del clero durante los siglos XI y XII.

A la pregunta por la existencia de las iglesias y monasterios propios en la Península Ibérica y en los nuevos espacios de la cristianitas pleno y bajomedieval y, por tanto, a la afirmación sobre la presencia del primero de los motivos de reforma que impulsó a los actores gregorianos, debemos contestar que las menciones documentales que se hicieron de este concepto en los primeros siglos medievales fueron tan abundantes que casi no resulta significativo entresacar ninguna.

Aunque debamos distinguir particularidades regionales, esta estructura estuvo presente tanto en los dominios de los magnates laicos, que podríamos denominar «señoriales», como en el seno de comunidades de campesinos o labradores que, en una behetría, o en un pre-concejo o concejo de pleno derecho, servían de centro espiritual y de percepción de las rentas de toda la comunidad cristiana.

3 Para la aplicación de la reforma en algunos territorios hispánicos, vid. FraZão dA Silva, Andréia Cristina Lopes. "A Reforma Gregoriana e o Bispado de Santiago de Compostela segundo a História Compostelana». Anuario Brasileño de Estudios Hispánicos, 2000, vol. 10, pp. 217-232; Martí Bonet, Josep Maria. «Sant Oleguer i l'aplicació de la Reforma Gregoriana». Acta Sacra Tarraconensia, 1998, vol. 71, pp. 537-579; Moráis Morán, José Alberto. «Nuevas reflexiones para la lectura iconográfica de la Portada del Perdón de San Isidoro de León: el impacto de la Reforma Gregoriana y el arte de la tardoantigüedad». De Arte: Revista de Historia del Arte, 2006, vol. 5, pp. 63-86; Palacios Martín, Bonifacio. "Castilla, Cluny y la Reforma Gregoriana». En El románico en Silos. Santo Domingo de Silos: Abadía de Silos, 1990, pp. 19-29; Toshiniro Abe, J. «La Reforma Gregoriana y Catalunya. Las relaciones entre la Iglesia y el poder secular, siglos XI y XII. De Ramón Berenguer I a Ramón Berenguer III». Acta Historica et Archaeologica Mediaevalia, 2006-2007, vol. 27-28, pp. 9-36; Vizuete MendozA, José Carlos. «La Reforma Gregoriana en Castilla a través de las disposiciones conciliares». En Estudios sobre Alfonso VI y la reconquista de Toledo. Toledo: Instituto de Estudios Visigóticos-Mozárabes, 1988, vol. 2, pp. 321-335.

4 Vid. Barrios García, Ángel. «Romanización y reconquista en la Península Ibérica: nuevas perspectivas». Cassiodorus, 1997, vol. 3, pp. 147-152; ÍDEM. "Conquista y repoblación: el proceso de reconstrucción del poblamiento y el aumento demográfico» y «Repoblación y colonización: la dinámica de creación de paisajes y el crecimiento económico». En Barrios García, Ángel (coord.). Historia de Ávila II. Edad Media (siglos VIII-XIII). Ávila: Institución Gran Duque de Alba, 2000, pp. 227-270 y 271-336; Casa MartíneZ, Carlos de la. «Despoblación y repoblación de los Extrema Durii». En Repoblación y reconquista. Actas del III Curso de cultura medieval. Aguilar de Campoo: Centro de Estudios del Románico, 1993, pp. 89-94. 
JOSÉ ANTONIO CALVO GÓMEZ

204

RASGOS DE LA REFORMA DEL CLERO EN LA PENÍNSULA IBÉRICA DURANTE EL SIGLO XI

La Península Ibérica tampoco permaneció al margen de las dificultades que, por la presencia de clérigos nicolaítas y simoníacos, sufrió la Iglesia occidental, fundamentalmente las viejas comunidades eclesiales del norte del Duero, insertas plenamente, desde siglos, en la llamada cristianitas, necesitadas ampliamente de una decidida actuación de los reformadores gregorianos.

Sin embargo, en la Península, la Reforma Gregoriana tuvo sus propios registros de interpretación y las particularidades regionales determinaron en gran medida la actuación de los agentes gregorianos. La implantación del nuevo derecho canónico, inspirado y administrado directamente por el pontificado, con la consiguiente pérdida representativa de las colecciones visigodas contenidas en la Hispana; la abolición del rito hispánico o mozárabe de acuerdo a la política unificadora de la curia romana y el reconocimiento en los reinos peninsulares de la soberanía pontificia; y la remodelación de los obispados, que incluyó el fortalecimiento de las sedes de Burgos y de Santiago de Compostela, y dejó preparada la confirmación de la sede toledana como primada de Espańa de la mano de Urbano II en 1088, ocuparon buena parte de las preocupaciones del papa Hildebrando con respecto a esta tierra, en la que el monacato cluniacense desarrolló, fundamentalmente, un programa de transmisión de la reforma, si bien contradictorio.

Los concilios representaron el primero y uno de los más importantes instrumentos en la erradicación de los males que afligían al clero peninsular, fundamentalmente la injerencia de los poderes laicos en la provisión eclesial, o investidura laica, la simonía y el nicolaísmo. Estas asambleas habían estado presentes en la historia de la Península Ibérica desde la época visigoda.

Con la recuperación de los territorios del norte y la puesta en marcha de los diversos planes de reforma que, en conjunto, puede llamarse Gregoriana, vinieron a ser agentes fundamentales para su extensión, en concomitancia con la actuación de los legados pontificios, muchos de los cuales intervinieron en su misma convocatoria y celebración.

Sin embargo, la restauración política, poco después de la pesadilla de Almanzor, en virtud de la nueva sabia inyectada en el tronco nacional por los condes de Castilla y por la dinastía navarra contra el anquilosamiento tradicionalista leonés, hizo que no hayamos de esperar al pontificado de Gregorio VII para descubrir en Espańa los primeros movimientos de restauración eclesiástica y de renovación moral y religiosa. Los concilios de León (1020) y Pamplona (1023), pero sobre todo los de Coyanza (1055) y Compostela (1056), así como los de Gerona y Vich (1068), señalaron el progreso de una conciencia cada día más vigilante con afanes de más perfecta organización y reforma.

En este horizonte de reforma, los canónigos regulares pretendieron ser una nueva propuesta de vida para encauzar las aspiraciones más elevadas de las nuevas generaciones de sacerdotes procedentes de la reforma ${ }^{5}$. Penetraron con fuerza en la Península y jugaron un papel destacado en la repoblación. Sin embargo, en general, el clero de la España reconquistada no vivió en común, como tampoco el de su antecesora visigótica, a pesar de las aspiraciones que formuló en el año 633 el canon 4 del concilio XXIII de Toledo. Más bien se debe hablar de una vida canonical como fruto tardío más vinculado a la Reforma

5 Vid. Calvo Gómez, José Antonio. «Los clérigos regulares de san Agustín en la Edad Media: un intento de conceptualización». Religión y Cultura, 2009, vol. 248, pp. 145-180. 
Gregoriana; es decir, no como una existencia corriente de los clérigos, sino como el alumbramiento de un estado religioso específico dentro de la Iglesia. Los canónigos regulares, aunque quisieron ser una renovación de la primitiva vida apostólica, constituyeron una innovación y una nueva realidad en la Iglesia -también en la Península Ibérica- al lado de los otros canónigos seculares y del monaquismo benedictino.

El 25 de mayo de 1085, en la ciudad italiana de Salerno, en cuya catedral reposan sus restos santos, "por amor a la justicia y odio de la iniquidad", murió desterrado el papa Gregorio VII, gozne y paladín de la reforma que lleva su nombre, asignado por implícito acuerdo de la historiografía clásica en virtud de una personalidad verdaderamente extraordinaria. El mismo día las tropas del rey Alfonso VI de León entraron definitivamente en la ciudad musulmana de Toledo, lo que representó la mayor consolidación de la posición cristiana en la lucha por la hegemonía de la plaza peninsular desde que se iniciara en algún momento, no fácil de precisar, a lo largo del siglo vin de la era cristiana ${ }^{6}$.

Como hemos indicado, la relación con los reinos hispánicos de los promotores de la Reforma Gregoriana, en general, y del papa Hildebrando, en particular, en la que se afrontó la renovación de la vida del clero y de las costumbres, así como la implantación de un nuevo derecho y del rito romano, en detrimento del rito mozárabe o hispánico, ahora en franco retroceso, llevó acuñados los sellos de la reconquista y la repoblación ${ }^{7}$.

6 El capítulo de la reconquista-colonización-repoblación de la Península Ibérica ha sido materia de debate entre diferentes autores a lo largo de más de cincuenta años. Vid. entre otros: BARrios García, Ángel. «Repoblación de la zona meridional del Duero. Fases de ocupación, procedencias y distribución espacial de los grupos repobladores». Studia Historica. Historia Medieval, 1985, vol. 3, pp. 33-82; Estepa Dítz, Carlos. El reinado de Alfonso VI. Madrid: Spainfo Ings, 1985; Gambra, Andrés. Alfonso VI. Cancilleria, curia e imperio. 2 vols. León: Centro de Estudios e Investigación San Isidoro, 1997-1998; GonzÁLEz, Julio. «La repoblación de la Extremadura leonesa». Hispania, 1943, vol. 11, pp. 195-273; ÍDEM. «La Extremadura castellana al mediar el siglo xiII». Hispania, 1974, vol. 127, pp. 265-424; Moxó y Ortiz de Villajos, Salvador de. Repoblación y sociedad en la España cristiana medieval. Madrid: Rialp, 1979. En los últimos años, los trabajos de Mínguez Fernández, José María. Alfonso VI: poder, expansión y reorganización interior. Hondarribia: Nerea, 2000, y de Martín Viso, Iñaki. "Capere vel populare. Formación y desarrollo de una frontera feudal entre el Duero y el Tajo (siglos XI- XIII)». En SABATÉ, Flocel (ed.). Balaguer 1105. Cruïlla de civilitzacions. Lleida: Pagès, 2007, pp. 177-223, enriquecidos con los resultados de las excavaciones arqueológicas en curso, han vuelto a plantear la conveniencia de los conceptos para definir la evolución de los territorios peninsulares a lo largo de los siglos pleno y bajomedievales.

Así lo han visto, entre otros, FACI LaCASTA, Javier. «La Reforma Gregoriana en Castilla y León». En García Villoslada, Ricardo (dir.). Historia de la Iglesia en España, II.1 ${ }^{\circ}$. La Iglesia en la España de los siglos VIII al XIV. Madrid: Editorial Católica, 1982, pp. 262-275. En el mismo sentido se pronuncia el profesor José Goñi Gaztambide, que redacta el artículo "Gregorio VII» en la Gran enciclopedia Rialp. Madrid: Rialp, 1984, vol. XI, pp. 324-327. Además de la obra citada de A. Fliche, para quien las afirmaciones del papa Hildebrando sobre España, en las que ahora profundizaremos, no tenían más que un significado general, sin pretensiones concretas, y del texto de García Villoslada, Ricardo. Historia de la Iglesia Católica. II, Edad Media (800-1303). Madrid: Editorial Católica, 1958, José Gońi sigue aquí la obra de Mansilla, Demetrio. La curia romana y el reino de Castilla en un momento decisivo de su historia (1061-1085). Burgos: Seminario Metropolitano, 1944, clásico en el estudio de esta etapa, y dos trabajos monográficos sobre el papa 


\section{6}

JOSÉ ANTONIO CALVO GÓMEZ

RASGOS DE LA REFORMA DEL CLERO EN LA PENÍNSULA IBÉRICA DURANTE EL SIGLO XI

La recuperación del antiguo solar visigodo condicionó poderosamente la actuación de los reformadores y la concepción del pontífice enlazó ambos empeños, que se materializó en las expediciones de la nobleza francesa dirigida por Ebuldo de Roucy y en la encomienda que recibió el cardenal Hugo Cándido cuando el papa Gregorio se dispuso a acompañar la flota que salió en defensa de Bizancio amenazado por los turcos ${ }^{8}$. De acuerdo a este proyecto, anotó el profesor Goñi, el Islam se vería atacado simultáneamente en Oriente y Occidente, con lo que se lograría la unión con la Iglesia griega y el rescate de la española?.

Con el tiempo, la oposición del rey Alfonso VI de León y Castilla $(1072-1109)^{10}$ y de Sancho I Ramírez de Aragón (1063-1094) ${ }^{11}$, que obligó a regresar a la expedición cruzada que envió, capitaneada por el duque Guillermo VIII de Aquitania, hizo reformular al papa sus pretensiones temporales, que había manifestado por medio de sus legados,

Gregorio VII: Morghen, Raffaello. Gregorio VII. Torino: Unione Tipografico-Editrice Torinese, 1942; y Arquillière, Henri-Xavier. Saint Gregoire VII. Essai sur sa conception du pouvoir pontifical. Paris: Librairie Philosophique J. Vrin, 1934.

${ }_{8}$ Vid. el manifiesto gregoriano Ad principes Hispaniae, que fecha en 30 de abril de 1073, en que explica que el reino de España perteneció antiguamente de derecho a San Pedro y que en estos momentos, todavía, aunque estuviese ocupado por paganos, ese derecho seguía siendo imprescriptible: «Non latere vos credimus regnum Hispaniae ab antiquo propii juris Sancti Petri fuisse, et adhuc (licet diu a paganis sit occupatam) lege tamen justitiae non evacuata, nulli mortalium, sed soli Apostolicae Sedi ex aequo pertinere... Itaque comes Evulus de Roceio... terram illam ad honorem Sancti Petri ingredi et paganorum manibus eripere cupiens, hanc concessionem ab Apostolica Sede obtinuit ut partem illam unde paganos suo studio et adjuncto sibi aliorum auxilio expellere posset, sub conditione inter nos factae pactionis ex parte Sancti Petri possideret». Epístola VII, Patrologia Latina. Paris, 1884-1856 (en adelante: PL), vol. 148, cols. 289-290.

9 Vid. también, sobre las pretensiones del papa Hildebrando, el trabajo de LlorCa, Bernardino. «Derechos de la Santa Sede sobre Espańa. El pensamiento de Gregorio VII». En FLIChE, Augustin y Martin, Victor. Historia de la Iglesia. VIII, Reforma Gregoriana y reconquista. Valencia: Edicep, 1976, pp. 551-575; OrLandis, José. «Reforma eclesiástica en los siglos XI y XII». En La Iglesia en la España visigótica y medieval. Pamplona: Ediciones Universidad de Navarra, 1976, pp. 309-343.

10 Castilla, que anexiona en 1035 el reino leonés, experimenta a partir de este momento un impulso hegemónico sin precedentes, donde las pretensiones proteccionistas de la Santa Sede son concebidas como un obstáculo más que como una posibilidad. El rey Alfonso VI utiliza la titulación de Imperator totius Hispaniae e incluso, en un diploma conservado en San Servando de Toledo, fechado al final de su reinado, se erige Gratia Dei Imperator super omnes Spaniae nationes, lo que lleva a ser más evidente durante el reinado de Alfonso VII. Gregorio VII, a partir de 1075, absorbido por el conflicto con Enrique IV, apenas puede atender a las dificultades hispanas que, por otro lado, un papa más diplomático como Urbano II reconduce por sendas de moderación y entendimiento.

${ }_{11}$ El caso de Aragón es diverso y no reviste la intensidad con que se aborda la materia en la corona castellana. El rey Sancho I acepta de mejor grado la conversión de su territorio en vasallo de San Pedro en 1068. El reino, debilitado entre el impulso de Castilla y la preponderancia de Navarra y de los condados catalanes, encuentra dificultades para continuar su expansión. Para Sancho Ramírez, su conversión en feudatario de la Santa Sede significa prestigio y legitimidad. Así lo ha estudiado Kenr, Paul. «Cómo y cuándo se hizo Aragón feudatario de la Santa Sede (estudio diplomático)». En Estudios de Edad Media de la Corona de Aragón, I. Zaragoza: Escuela de Estudios Medievales, 1945, pp. 285-326. Vid. KeHR, Paul. Das papsttum und die Königreiche Navarra und Aragon bis zur Mitte des XII. Jarhunderts. Berlin: Akademie der Wissenschaften, 1928; y, sobre todo, ÍDem. Wie und wann wurde das Reich Aragon ein Lehen der römischen Kirche? Berlin: Akademie der Wissenschaften, 1928. 
fundamentalmente Frotardo de San Ponce y Amando de Olorón, así como de diferentes textos pontificios ${ }^{12}$.

Al fracaso del envío de Ebuldo de Roucy, quien habría recibido en posesión feudal cuantos espacios arrancase a las taifas musulmanas, se unió luego la resistencia de los reinos peninsulares a aceptar la propiedad pontificia del territorio en disputa con el Islam, no menor de la que encontró en su proyecto de implantación del nuevo rito romano ${ }^{13}$. Esta consideración obligó a delimitar con precisión los marcos espaciales en los que aconteció la reforma del clero peninsular. En una simplificación amplia, que conlleva no poca imprecisión, se podrían distinguir dos territorios, fundamentalmente, que encarnaron otras tantas actuaciones del proyecto reformador.

Existió una Iglesia ampliamente consolidada en las estructuras de la cristiandad medieval, aunque el término exige cierta explicación. Sin abordar ahora el problema de la limitada o diferida feudalización de la Península Ibérica ${ }^{14}$ ni la particular evolución histórica de la Marca Hispánica ${ }^{15}$, no cabe duda de que los territorios situados al norte de los ríos Duero y Ebro y, tal vez, aunque en menor medida, a partir de mediados del siglo x, las cuencas medias de los ríos Tormes y Eresma, en las provincias actuales de Salamanca y Segovia, sometidos desde primera hora a los reyes cristianos, se encontraban sujetos a las mismas necesidades de reforma que se descubrieron en los reinos allende los Pirineos.

La vida de un monasterio benedictino del norte de Burgos distaba muy poco, a finales del siglo XI, de cuanto sucedía entre los muros de una abadía del Mediodía francés o del centro del Sacro Imperio Romano Germánico. Sin embargo, los envites de la reconquista imposibilitaron la implantación de una vida clerical, secular o regular, y de una vida monástica, en los territorios de los Extrema Durii hasta poco antes de la definitiva

12 El 28 de junio de 1077 escribe una nueva carta Ad Hispanos en que completa la doctrina sobre la preeminencia de la Sede Apostólica sobre los reinos españoles, entregados a San Pedro en derecho y propiedad: "Non ignorare credimus prudentiam vestram, qui Sancta et Apostolica Sede princeps et universalis mater sit omnium Ecclesiarum et gentium quas divina clementia ad agnitionem sui nominis in fide Domini... per evangelicam et apostolicam doctrinam venire praeordinavit; quibus hanc curam et perpetuam debet exhibere sollicitudinem, ut, sicut ad conservandam catholicae fideli veritatem, ita quoque ad cognoscendam et tenendam justitiam documenta et salutifera administret monita». El papa insiste en la obligación de los reyes hispanos de colaborar con la causa pontificia en la reconquista de los territorios que yacen bajo el yugo sarraceno y recuperar así su justicia y honor: «Dum postquam regnum illud a saracenis et paganis pervasum est, et servitium quod beato Petro inde solebat fieri, propter infidelitatem eorum et tyrannidem detentum, ab usu nostrorum tot annis interceptum est, pariter etiam rerum et proprietatis memoria dilabi coepit. Verum quia divina clementia concessa vobis in hostes illos semperque concedenda victoria terram in manus vestras tradidit, ulterius vos causam hanc ignorare nolumus, ne quod supernus arbiter et legum ac justitiae et honore Sancti Petri... vestrae gloriae ad bene merendum contulit... ad detrimentum propositae et divinitus oblatae retributiones obveniat». Epístola XXVIII, PL 148, cols. 483-488.

13 Goñi Gaztambide, José. Historia de la Bula de la Cruzada en España. Vitoria: Editorial del Seminario, 1958, pp. 52-55.

14 Para un tratamiento pormenorizado del tema en la Península Ibérica, vid. las ponencias de los profesores R. Pastor, J. L. Martín, J. Valdeón, M. a I. Alfonso y A. Barbero en el congreso En torno al feudalismo hispánico. I Congreso de estudios medievales. Ávila: Fundación Sánchez-Albornoz, 1989. No obstante, un tema que planteó conocidos debates a lo largo de las tres últimas décadas del siglo xx, ha perdido cierta actualidad en los últimos años, relegado bajo el influjo de los nuevos estudios de género y de las mentalidades.

15 Vid. Rodríguez-Picavea Matilla, Enrique. La Corona de Aragón en la Edad Media. Tres Cantos (Madrid): Akal: 1999. 
JOSÉ ANTONIO CALVO GÓMEZ

puesta en valor de los proyectos de reforma que tuvo entre sus más decididos protagonistas de la primera hora al papa León IX, al cardenal de Silva Cándida y la formulación del problema de las investiduras en 1058, y los decretos del sínodo de Letrán de 1059. La implantación de la cristianitas en los nuevos territorios recuperados del Islam desde mediados del siglo XI vino marcada en mayor medida por la idea de una nueva visión del mundo, ya reformado, que había calado, aunque con graves dificultades, en la política de los repobladores.

En definitiva, debemos abordar el estudio de los acontecimientos que jalonaron la implantación de la Reforma Gregoriana del clero en la Península Ibérica en su doble actuación. Por un lado, se asistió a la renovación de la Iglesia del norte, asentada siglos atrás, especialmente necesitada de una actuación que llegó de la mano de los sínodos diocesanos, la generalización de la nueva disciplina canónica, la erección de nuevos monasterios, sobre todo cistercienses, y la implantación del rito romano en detrimento del viejo rito mozárabe o hispánico entonces en recesión.

Por otro, se descubre la extensión de los postulados gregorianos en la nueva cristiandad, en unos nuevos territorios en evolución y desarrollo. Allí la reforma fue de la mano de la conformación de las nuevas estructuras eclesiales y de la fundación de nuevos monasterios, que adquirieron nuevas trazas a la luz de esta misma reforma. En este punto debe abordarse la vida de los canónigos regulares que pretendieron ser, aunque sin llegar a conseguirlo, el instrumento para la renovación de la vida del clero en la Iglesia reformada ${ }^{16}$.

Ciertamente no cabe suponer una ruptura en esta doble actuación, que se dio en simultaneidad. Es decir, aunque debamos diferenciar los procesos en orden a su clarificación, el proyecto fue único y en el mismo sentido. Los actores de la reforma procedieron a su extensión por la vía de la transformación de las viejas estructuras ya existentes al tiempo que provocaron la reduplicación de estas mismas estructuras, una vez reformadas, en los nuevos territorios recientemente conquistados.

\section{Las iglesias propias en la Península en el siglo XI}

En algunos estudios, dedicados a la historia medieval de la Iglesia en la Península Ibérica, pareció indicarse que, en este territorio, en el marco de la Reforma Gregoriana, no estuvo presente el problema de la investidura laica o que, en todo caso, habría sido objeto de preocupación solo muchos años después ${ }^{17}$. Existió otra opinión, que por otro

16 Vid. Calvo Gómez, José Antonio. «Aproximación a la historia de los clérigos regulares de san Agustín en la Península Ibérica». Religión y Cultura, 2009, vol. 251, pp. 829-874.

17 Vid. sobre todo, los trabajos de Sánchez-Albornoz, Claudio. España, un enigma histórico. Buenos Aires: Editorial Sudamericana, 1956; e ÍDEm. Despoblación y repoblación del valle del Duero. Buenos Aires: Instituto de Historia de España, 1966; pero también: MenéNDez Pidal, Ramón. «Repoblación y tradición en la cuenca del Duero». En Enciclopedia lingüistica hispánica. Madrid: Consejo Superior de Investigaciones Científicas, 1960, vol. I, pp. 29-57; Ídem. La España del Cid. 6. ${ }^{a}$ ed. Madrid: Espasa-Calpe, 1967; y, como expresión actual de la obra de su maestro, la aportación de PASTOR, Reyna. «Claudio Sánchez Albornoz, historiador, maestro y militante». En Pastor, Reyna (dir.). Sánchez-Albornoz a debate. Homenaje en la 
lado no aportó documentación fehaciente alguna, que mantuvo la tesis de la devolución voluntaria de iglesias y monasterios, antecedente a la reforma, y que, por tanto, habría hecho inútil la misma actuación gregoriana por reiterativa. Es necesario despejar la duda que, durante años, ha sobrevolado a la investigación histórica en cuanto a la realidad de la «iglesia propia» en la España de la Reforma Gregoriana y, por extensión, de la presencia o no de la investidura laica como mecanismo de regulación de esta estructura de componentes políticos y pastorales.

Algunos autores negaron su existencia o la retrasaron hasta etapas muy posteriores, al tiempo que forzaron hasta lo incomprensible aquella misma singularidad hispánica, la tercera vía ibérica, como pauta de explicación de todo cuanto no encajaba en el devenir común de la Iglesia y la cultura europeas.

Javier Faci Lacasta, autor de diversos trabajos relativos a la historia socio-económica y política medieval, estudió con cierto detalle el capítulo relativo a las iglesias propias en España ${ }^{18}$. Según este autor, esta estructura se relacionó directamente con la evolución económica y social de los principados cristianos peninsulares durante la Alta Edad Media en el camino que fue desde las diversas estructuras sociales previas que existieron en la zona pirenaica y astur hacia el feudalismo. El rechazo a la idea de la feudalización primitiva de la Península Ibérica llevó implícita la negación de aceptar la existencia de esta estructura jurídico-pastoral en este territorio ${ }^{19}$.

El propio Faci, al abordar la explicación global de este fenómeno, afirmó que la actuación de los reformadores gregorianos se limitó a la regulación del régimen de las «iglesias propias», sin llegar a conseguir su desaparición, que necesitó de un marco jurídico de actuación y un desarrollo del derecho canónico más amplio, como el que tuvo lugar en torno a la redacción del Decreto de Graciano en 1140. Solo el concilio III de Letrán de 1179 resolvió canónicamente esta irregularidad eclesiológica, no sin resistencia, al reservar al fundador de la iglesia exclusivamente el derecho de patronato ${ }^{20}$.

Universidad de Valladolid con motivo de su centenario. Valladolid: Universidad de Valladolid, 1993, pp. 3344. En contrapartida, vid. Mínguez Fernández, José María y Ser Quijano, Gregorio del (coords.). La Peninsula en la Edad Media: treinta años después. Estudios dedicados a José-Luis Martín. Salamanca: Ediciones Universidad de Salamanca, 2006; y FACI LACASTA, «La Reforma Gregoriana», pp. 262-275. Este último autor menciona sobre el particular: «Estamos convencidos de que la situación moral por la que atravesaban las iglesias de los reinos cristianos del norte a mediados del siglo xi era bastante semejante a la de los demás reinos de Europa occidental, aunque su plasmación directa, como es lógico, difiriese».

18 Faci Lacasta, Javier. «La iglesia propia en España». En García Villoslada, Historia de la Iglesia en España, II.1º, pp. 136-139. Vid. también Rodríguez GiL, Magdalena. «Consideraciones sobre una antigua polémica: las iglesias propias». Cuadernos de Historia del Derecho, 1999, vol. 6, pp. 247-272.

19 Vid. Álvarez Borge, Ignacio. Monarquía feudal y organización territorial. Alfoces y merindades en Castilla (siglos X-XIV). Madrid: Consejo Superior de Investigaciones Científicas, 1993; Barrios García, Ángel. «Del Duero a Sierra Morena: estructura y expansión del feudalismo medieval castellano». En Má́llo SALGADo, Felipe (ed.). España, Al-Andalus, Sefarad: sintesis y nuevas perspectivas. Salamanca: Ediciones Universidad de Salamanca, 1988, pp. 37-48; ÍDEM. "Repoblación y feudalismo en las Extremaduras». En En torno al feudalismo hispánico. I Congreso de estudios medievales, pp. 417-433; ÍDEM. «La formación del feudalismo en la Península Ibérica». En Romanización y reconquista en la Península Ibérica: nuevas perspectivas. Salamanca: Ediciones Universidad de Salamanca, 1998, pp. 11-24.

20 La obra de Ulrich Stutz (Zúrich 1868-Berlín 1938), representa el primer intento de conceptualizar esta realidad que él denomina Eigenkirche, capilla u oratorio privado sobre el que los laicos se arrogarían 
La regulación canónica -y en cierto sentido el primer brete para su desapariciónsobre las «iglesias propias» en la Península Ibérica, tras la consolidación bajo la corona leonesa de los territorios al norte del Duero, comenzó con los decretos del concilio de Coyanza de $1055^{21}$, situados crecidamente al margen de los procesos generales de reforma eclesial, donde siguió muy de cerca el marco teórico doctrinal de la legislación visigoda sobre el particular ${ }^{22}$.

De acuerdo a la explicación que dio con más detalle Alfonso García Gallo ${ }^{23}$, junto a otras consideraciones sobre el ornato de los templos, la misa y los ministros del altar, el capítulo III estableció que todos ellos, es decir, las iglesias, monasterios y sus clérigos, dependieran exclusivamente del obispo y de su superior eclesiástico, y no de laico alguno, por bienintencionado que se supusiera. Esta regulación contribuyó de manera definitiva

derechos de propiedad, resultado, según este autor, que se apoya en algunos textos de Tácito desfasados cronológicamente y poco claros, de la evolución de los templos familiares de los pueblos germánicos. Vid. StuTz, Ulrich. Ausgewählte Kapitel aus der Geschichte der Eigenkirche und ihres Rechtes. Weimar: Verlag Hermann Böhlaus Nachfolger, 1937; Ídem. Die Eigenkirche: als Elements des Mittlelalterlich-germanischen Kirchenrechts. Darmstadt: Wissenschaftliche Buchgesellschaft, 1955. Diversos autores, que reconocen la profundidad y originalidad de la obra de Ulrich Stutz, entre los que se encuentra el propio Faci Lacasta, le acusan de haber caído en la falsa oposición, que por otro lado inunda la obra de todo el medievalismo de finales del siglo XIX, entre romanismo y germanismo, ampliamente criticada en la actualidad. Las posiciones de Stutz encuentran sus más aguerridos opositores entre los seguidores de Fustel de Coulanges (París 1830-Massy 1889), calificado de "romanista» por la historiografía contemporánea. En su obra La cité antique. Paris: Durand, 1864, Coulanges critica los resultados de Stutz al analizar las relaciones entre la propiedad y las instituciones político-religiosas, estudio que completa en Histoire des institutions de l'ancienne France. Paris: Librairie Hachette, 1874; así como en Recherches sur quelques problèmes d'histoire. Paris: Librairie Hachette, 1885. A principios del siglo pasado -la primera edición de su obra se publica en Alemania en 1918- Alfons Dopsch ensaya una visión más ponderada del problema al relegar a un segundo plano los componentes étnicos germánicos y relacionar la institución de las «iglesias propias» con el proceso de la seńorialización de la sociedad romana tardía. Vid. Dopsch, Alfons. Fundamentos económicos y sociales de la cultura europea. De César a Carlomagno. Madrid: Fondo de Cultura Económica, 1951.

21 Mansi, Giovan Domenico. Sacrorum Conciliorum nova et amplissima collectio. Graz: Akademische Druck- u. Verlagsanstalt, 1961, vol. 19, pp. 785-794.

22 La legislación canónica visigoda se apoya en las disposiciones particulares de otras iglesias, como el concilio de Orange del 441 o el de Arlés del 452, así como en textos pontificios como la carta decretal del papa Gelasio I del año 494. El objeto de esta materia legal es asegurar la autoridad de los obispos, bajo cuyo control y jurisdicción pone todas las iglesias privadas, al tiempo que autoriza su fundación solo cuando se realiza con dotación suficiente y se asegura el culto efectivo. Javier Faci añade que «la primera disposición canónica hispánica proviene del canon III del concilio de Lérida de 546, en el que se establece una clara diferencia entre el régimen patrimonial de un monasterio, independiente de la autoridad episcopal, y el de una basílica fundada por un laico, sometida en todo a dicha jurisdicción. El concilio II de Braga vuelve a ocuparse del tema en sus cánones V y VI, reiterando la exigencia de la dotación por parte del fundador y la prohibición de ser llevada a cabo con afán de lucro. Diversos concilios toledanos posteriores, en particular el III y el IV, reiteraron la total autoridad de los obispos sobre las iglesias privadas, tanto en lo religioso como en lo patrimonial. Sin embargo, esta misma legislación va otorgando a los fundadores algunas prerrogativas, como la presentación del clérigo, el ejercicio de un cierto control sobre el obispo, para que este no cometa abusos ni arbitrariedades, etc.». Vid. FACI LaCASTA, «La iglesia propia en España», pp. 137-138; VIVes, José. Concilios visigóticosos e hispano-romanos. Madrid: Instituto Enrique Flórez, 1963, pp. 56-83.

23 García Gallo, Alfonso. «El concilio de Coyanza. Contribución al estudio del derecho canónico español en la Alta Edad Media». Anuario de Historia del Derecho Español, 1950, vol. 20, pp. 275-633; ÍDEm. «Las redacciones de los decretos del concilio de Coyanza». Archivos Leoneses, 1951, vol. 9, pp. 25-39. 
al fortalecimiento de la jerarquía episcopal y, en este sentido, resultó ampliamente coincidente con los postulados del papa Hildebrando y de los demás artífices de la Reforma Gregoriana ${ }^{24}$.

A la pregunta por la existencia de las iglesias y monasterios propios en el antiguo solar visigodo y en los nuevos espacios de la cristianitas pleno y bajomedieval la respuesta del profesor Faci no admite réplica: «La abundancia de menciones documentales... en los primeros siglos medievales es tan grande que casi no resulta significativo entresacar algunas. Tuvieron este carácter tanto las de los magnates laicos en sus dominios, a las que podríamos denominar como señoriales, como las establecidas por comunidades de campesinos o labradores que, en una behetría, o en un "preconcejo" o concejo de pleno derecho, servían de centro espiritual y de percepción de rentas de la comunidad ${ }^{25}$.

No faltan dificultades para aclarar la situación de las iglesias propias, en particular, y de la organización política y eclesiástica del reino astur, en general, de la primera época de su existencia, tras la invasión musulmana. Pero la aparición del concepto de la «iglesia propia», a veces confundido bajo la denominación de "monasterio propio», fue ligada a los primeros diplomas que se conocieron, a finales del siglo viII.

A partir de este momento, la diplomática explicó bien la actividad religiosa y repobladora de las pequeñas células monásticas, de inspiración fructuosiana, que tanta importancia tuvieron durante el reino visigodo. Los documentos de fundación y de cesión de bienes dejaron barruntar la realidad, todavía no conceptualizada, de las iglesias y monasterios propios. Estas instituciones, en manos laicas, contribuyeron eficazmente a la colonización y posterior repoblación de los nuevos territorios.

En este punto, Faci estableció una doble orientación documental que tradujo una diversa realidad eclesial entre la iglesia astur y la de los estados orientales. En cuanto a la primera, se observó una presencia muy significativa de arcaísmos, producto de una peculiar organización social, y de una ausencia de elementos visigodos, como la organización episcopal, piedra angular de la organización eclesiástica romana y visigoda, exceptuadas las dudosas menciones a un cierto obispo Odoario, que habría repoblado Lugo a mediados del siglo viII, o al "episcopus» Juan de Valpuesta a principios del Ix. Solo la llegada de numerosos mozárabes a finales del siglo ix hizo que la aportación de elementos godos resultara más significativa.

En las Iglesias orientales, por el contrario, aunque existieron también indudables elementos arcaizantes, la presencia visigoda se hizo más evidente, como la que manifestó el conocimiento y uso del Liber Iudiciorum y de la Hispana en las montañas del Pirineo,

24 «La documentación de los principales monasterios peninsulares -completa Javier Faci- nos da cuenta, durante el siglo XII, de la fuerte pugna entre los grandes monasterios y los obispos por el control de las iglesias de cada diócesis, creadas en una época en que éstas no existían más que de nombre y los monasterios eran los únicos capacitados para la cura de almas. Estos mismos documentos nos dan cuenta de la victoria de los obispos, según las directrices generales de la Iglesia, por más que en muchos casos el control y la cura de almas siguiese en manos no episcopales, aunque reconociendo la supremacía episcopal». Vid. FACI LACASTA, «La iglesia propia en Espańa», p. 139. Vid. nuestro trabajo: Calvo Gómez, José Antonio. «El reiterado conflicto sobre la jurisdicción eclesiástica entre el obispo de Ávila y el abad de Santa María de Burgohondo (siglos XI-XIX)». Anthologica Annua, 2004-2005, vol. 51-52, pp. 247-434.

25 FaCi LaCasta, «La iglesia propia en España», 139. 
que pasaron a Francia precisamente desde Cataluña. La influencia carolingia hizo que se perpetuaran con mayor intensidad las instituciones eclesiásticas de la Antigüedad, espacio sobre el que el régimen de las «iglesias propias», en profunda relación con los procesos de señorialización y feudalización, se insertó sin ninguna dificultad.

El reino asturleonés, que experimentó un proceso de señorialización y feudalización diverso, llegó al régimen de las «iglesias propias» por otro camino, en un marco ideológico y jurídico diverso, pero no por ello menos vigente y con menor eficacia que en los estados orientales. Solo la negación del sistema feudal en la Península Ibérica hizo que se pusieran en entredicho las instituciones que le eran anejas. La respuesta a esta «tercera vía ibérica» fue contundente entre los historiadores que hemos citado arriba.

Otros autores que se ocuparon con anterioridad del problema de las iglesias y monasterios propios fueron, sobre todo, Manuel Torres López, que aplicó la concepción que, sobre esta idea, circuló en la historiografía europea a la realidad hispánica, y el padre jesuita Ramón Bidagor, de la Universidad Gregoriana de Roma.

Manuel Torres publicó entre 1925 y 1928 los estudios programáticos sobre la «iglesia propia» en España ${ }^{26}$. En ellos tradujo el término Eigenkirche por «iglesia propia» como concepto que recogió con fidelidad la tradición diplomática del Medioevo peninsular. Sin embargo, estos textos no abordaron el estudio de las peculiaridades de la institución y más bien se limitaron a discutir, metodológicamente, los puntos de vista al respecto y la búsqueda de la tradición doctrinal específicamente hispánica.

El padre Bidagor, por su parte, limitó su estudio, publicado en 1933, a los aspectos jurídico-canónicos de la institución, evitando deliberadamente los contenidos socioeconómicos, sin avanzar en el conocimiento de la doctrina a los postulados que, años atrás, formulara Manuel Torres de forma brillante ${ }^{27}$. Este hecho llevó a afirmar al profesor Faci, a la altura de 1982, que seguía faltándonos una investigación concreta y sistemática de las «iglesias propias» en la Edad Media española ${ }^{28}$.

Aclarado el problema de la existencia de las «iglesias propias» en la Península Ibérica, resulta más sencillo comprender el conflicto de las investiduras en el marco de actuación

26 Torres López, Manuel. «La doctrina de las "iglesias propias" en los autores españoles». Anuario de Historia del Derecho Español, 1925, vol. 2, pp. 402-461; IDEM. "El origen del sistema de las "iglesias propias"». Anuario de Hstoria del Derecho Español, 1928, vol. 5, pp. 83-217.

27 Bidagor, Ramón. La «iglesia propia» en España. Estudio histórico-critico. Romae: apud aedes Pontificiae Universitatis Gregorianae, 1933.

28 Vid. también otros autores, como MarTínez Díez, Gonzalo. «La Iglesia de Burgos. Desde la invasión musulmana hasta el traslado de la sede de Oca a Burgos: 711-1081». En Bartolomé Martínez, Bernabé (coord.). Historia de las diócesis españolas. 20, Iglesias de Burgos, Osma-Soria y Santander. Madrid: Biblioteca de Autores Cristianos, 2004, pp. 13-41, especialmente pp. 37-41, donde trata de mostrar el estado de la cuestión de las «iglesias propias» en los obispados castellanos y de establecer un modelo explicativo sobre su origen, basado de nuevo en la idea de la colonización espontánea de nuevos territorios durante la reconquista y en la respuesta de numerosas poblaciones de nuevos cristianos tras el colapso de las sedes episcopales y la estructura diocesana después del 711. Según este autor, en la diócesis de Oca, luego burgalesa, «el número de estas iglesias rurales, prácticamente casi todas bajo el sistema de "iglesias propias", era tan abundante que no había aldea por pequeña que fuera que no contara con su propia iglesia... en manos de particulares, que disponen de ella como de un bien cualquiera, sea donándolas, vendiéndolas o dejándolas en herencia... El propietario de la iglesia disponía en su provecho de sus frutos y de las ofrendas que los fieles presentaban... El clero... era elegido por el propietario y presentado al obispo bien para su ordenación, bien para su confirmación en la iglesia en cuestión». 
de la Reforma Gregoriana. Si la documentación medieval no mencionó el concepto de la investidura laica se debió, fundamentalmente, a que no existió, en sentido propio, una articulación institucional entre relación de dependencia personal y cesión de bienes eclesiásticos, patente en la Iglesia occidental.

Sin embargo, la realidad económica y social para este conflicto estuvo presente en la historia de los reinos cristianos del norte de España durante buena parte de los siglos viıI al xi. Solo en relación con los territorios de los Extrema Durii, en trance de repoblación, cabría formular una valoración diversa ${ }^{29}$. En aquel momento, tanto los reyes como los diversos títulos nobiliarios gozaron de fuerza y gran autoridad sobre los espacios de la jurisdicción eclesiástica, que se vio compensada con la intromisión más que circunstancial de los obispos y abades de los principales monasterios en los asuntos propios de la justicia y la administración civil. Si la formulación externa fue más difícil de localizar en la documentación castellana del siglo XI, el sustrato ideológico de actuación fue el mismo que soportó la estructura de la investidura laica que, poco tiempo después, sobre todo a raíz del concilio romano de 1075, en el nivel de las relaciones internacionales, provocó la mencionada querella entre el pontificado y los diversos reinos de la cristiandad occidental ${ }^{30}$.

\section{LOS PECADOS DEL CLERO PENINSULAR}

La Península Ibérica no permaneció al margen de las dificultades que sufrió la Iglesia occidental, fundamentalmente la vieja Iglesia del norte del Duero, inserta plenamente desde siglos en la llamada cristianitas y necesitada, como ella, de una decidida actuación de los reformadores gregorianos ${ }^{31}$. Resulta intelectualmente necesario abordar los casos concretos para poner de manifiesto la hondura con que enraizó en esta tierra la investidura laica, así como para responder a la pregunta por la fuerza con que brotaron aquí sus dos

29 Vid. Faci Lacasta, «La Reforma Gregoriana», p. 268. A pesar de las diferentes condenas sinodales y pontificias, las iglesias propias y su problemática aneja reaparecerá una y otra vez en la documentación castellana durante toda la Edad Media, aunque ocultas bajo diversos apelativos, a veces confundidas como «iglesias patrimoniales». Vid. Peñalva Gil, Jesús. «Las iglesias patrimoniales en la Castilla medieval. La iglesia parroquial de San Nicolás de Burgos: institución, ordenanzas y regla de 1408». Anuario de Estudios Medievales, 2008, vol. 38/1, pp. 301-366. Vid. también Catalán Martínez, Elena. «El derecho de patronato y el régimen beneficial de la Iglesia española en la Edad Moderna». Hispania Sacra, 2004, vol. 56, pp. 135-167, quien, como preámbulo a la breve lectura más económica que histórica que se haga de esta realidad en la Edad Moderna, hace un interesante y amplio repaso por la problemática de las «iglesias propias» en Espańa, y las diferencias de matiz que se establecen con las «iglesias patrimoniales» y «de patronazgo», para llegar al control de los «beneficios propios» e incluso «clérigos privados», que necesitaría, todavía, un poco más de tiempo a la luz de las propuestas y los resultados de la Reforma Gregoriana.

30 Vid. Llorca, «Derechos de la Santa Sede sobre España», p. 554, donde analiza la posición crítica que mantienen historiadores como C. Hampe, G. Ficker e incluso R. Menéndez Pidal, a quien acusa de dejarse llevar en este punto por los prejuicios liberales al escribir su obra La España del Cid.

31 No todos los autores lo ven así. V. gr. Ricardo García Villoslada atribuye a la actuación de los condes de Castilla y de la dinastía navarra, como reacción a las algaradas de Almanzor, y a Fernando I de Castilla y León (1037-1065), la reforma religiosa de los territorios peninsulares con anterioridad a la gregoriana y hacer de esta, en lo que concierne a sus puntos capitales, el nicolaísmo y la simonía, menos necesaria aquí que en otros lugares de la cristiandad. Vid. García Villoslada, Historia de la Iglesia Católica, II, pp. 327-336. 
hijos naturales: la simonía y el nicolaísmo, que ocuparon buena parte de los postulados y actividades de los actores de la Reforma Gregoriana ${ }^{32}$.

En la Península Ibérica, sin embargo, la Reforma Gregoriana tuvo sus propios registros de interpretación ${ }^{33}$. Sin renunciar a la idea de la necesidad de una misma reforma en las estructuras de la Iglesia peninsular, singularmente, por lo que toca a esta investigación, en lo que al clero se refiere, de la que se descubre en las demás naciones de la cristianitas occidental, no cabe duda de que las particularidades regionales determinaron en gran medida la actuación de los agentes gregorianos.

La implantación del nuevo derecho canónico, inspirado y dirigido directamente por el pontificado, con la consiguiente pérdida representativa de las colecciones visigodas contenidas en la Hispana ${ }^{34}$; la abolición del rito hispánico o mozárabe de acuerdo a la política unificadora de la curia romana y el reconocimiento en los reinos peninsulares de la soberanía pontificia ${ }^{35}$; y la remodelación de los obispados, que incluyó el fortalecimiento de la sede de Burgos o la de Santiago de Compostela y dejó preparada la confirmación de la sede toledana como primada de Espańa de la mano de Urbano II en 1088, ocuparon buena parte de las preocupaciones del papa Hildebrando con respecto a esta tierra.

En la Península el monacato cluniacense ejerció fundamentalmente un programa de transmisión de la Reforma Gregoriana, si bien, como apuntó Javier Faci, en un

32 Vid. García Villoslada, Historia de la Iglesia Católica, II, pp. 295-336.

33 Entre los que han tratado el tema específico de la Reforma Gregoriana en la Península Ibérica, además de los estudios sobre determinados aspectos, como los sínodos o los canónigos regulares, vid. CALZADA, Luciano de la. «La proyección del pensamiento de Gregorio VII en los reinos de Castilla y León». Studi Gregoriani, 1948, vol. 3, pp. 1-87; Defourneaux, Marcelin. Les français en Espagne aux XI et XII siècles. Paris: Presses Universitaires de France, 1949; Durán Gudiol, Antonio. «La Iglesia en Aragón durante el siglo XI». En Estudios de Edad Media de la Corona de Aragón, IV. Zaragoza: Escuela de Estudios Medievales, 1951, pp. 7-68; García Villada, Zacarías. Organización y fisonomía de la Iglesia española desde la caída del Imperio visigodo en 711, hasta la toma de Toledo en 1085. Madrid: [s. n.], 1935; HerLiny, David. «Church property on the European Continent». Speculum, 1961, vol. 36, pp. 81-102; Mansilla, La curia romana y el reino de Castilla; Kenr, "Cómo y cuándo se hizo Aragón feudatario de la Santa Sede»; Ídem, Das papsttum und die Königreiche Navarra und Aragon; ÍDEM, Wie und wann wurde das Reich Aragon; OrLANDIs, «Reforma eclesiástica en los siglos XI y XII»; SERRANO, Luciano. El obispado de Burgos y Castilla primitiva desde el siglo V al XIII. Madrid: Instituto de Valencia de don Juan, 1935-1936, 3 vols., entre otros.

34 En este sentido, también se produce una ruptura de la administración gregoriana con la reforma jurídica iniciada, para la Península Ibérica, con el concilio de Coyanza (1055), en el que fundamentalmente se postula una recuperación tradicionalista del antiguo orden visigodo. Vid. García GaLlo, «El concilio de Coyanza»; ÍDEM, «Las redacciones de los decretos del concilio de Coyanza».

35 Dice Gońi que con el fin de introducir el rito romano y abolir a toda costa el mozárabe, de acuerdo a la política unificadora de la curia romana, vinieron a la Península Ibérica «varios legados, pero tropezaron con la resistencia de los obispos. El primer reino que se plegó a las exigencias curiales fue el aragonés, y más concretamente el monasterio de San Juan de la Peña. Aquí, el 22 de marzo de 1071 se cantó prima y tercia según el rito toledano, pero desde sexta se observó la ley romana. Desde el monasterio pinatense el oficio romano se extendió a las iglesias y monasterios del reino. En Navarra, el cambio de rito se verificó a raíz del concilio romano de 1074. Castilla abandonó la liturgia hispánica en 1078 por imposición del rey». Vid. GoÑ Gaztambide, «Gregorio VII», p. 327, que lo toma de Rivera, Juan Francisco. «Gregorio VII y la liturgia mozárabe». Revista Española de Teología, 1942, vol. 2, pp. 3-33. 
papel contradictorio ${ }^{36}$. Este autor recordó cómo a través de estos monjes surgieron los primeros estímulos reformadores que, con el tiempo, llegaron a la esfera pontificia. El propio Hildebrando, futuro papa Gregorio VII, muerto su protector Gregorio VI en 1047, se retiró a la abadía de Cluny, donde recibió el hábito benedictino. Luego en Roma, el papa León IX, después de crearle cardenal en 1049, le encomendó el gobierno de un nuevo monasterio, el de San Pablo Extramuros, de costumbres muy relajadas, donde emprendió una decidida reforma al tiempo que restauró ampliamente su basílica.

En contrapartida, algunos monjes cluniacenses, como Roberto de Sahagún, se enfrentaron gravemente, por el cambio de rito, contra el legado pontificio y canónigo regular Ricardo de San Víctor. Esta situación se transmitió a la relación del propio Gregorio VII con san Hugo, que se percibió como tensión en las cartas que se intercambiaron. El profesor Faci anotó que «las aguas volvieron a sus cauces normales y la colaboración habitual entre los monjes negros y el papado se restableció», especialmente en los pontificados siguientes de Urbano II (1088-1099) ${ }^{37}$ y Pascual II (1099-1118), dos monjes de Cluny. De hecho, entre los cluniacenses venidos a España, encontramos algunas de las figuras más importantes de esta nueva Iglesia cristiana de la Península, como Bernardo de Sauvetat, primer arzobispo de Toledo.

En este marco deben analizarse dos actuaciones encaminadas a la renovación del clero en la Península Ibérica en consonancia con la Reforma Gregoriana: la convocatoria de concilios y sínodos, nacionales o diocesanos, en los que se pretendió atajar los males principales que le aquejaban; y la fundación de los canónigos regulares, que pretendieron ser una propuesta de vida renovada encaminada a encauzar las aspiraciones más elevadas de las nuevas generaciones de sacerdotes, procedentes de la reforma.

Antes de dar paso a estas consideraciones, sintetizamos en palabras del propio Javier Faci cuanto hemos tratado de expresar arriba sobre la peculiaridad o no del caso hispano sobre esta materia: «No cabe minimizar la importancia de la Reforma Gregoriana en la Península. Se ha ido viendo que los problemas que planteaban las Iglesias peninsulares eran semejantes a las del resto de Europa y, por tanto, también las soluciones se asemejaban. También se ha podido apreciar que España no quedaba... fuera de los planes hegemónicos del pontificado, sino que ocupaba en ellos un papel muy importante. La reorganización eclesiástica que experimenta la cristiandad como consecuencia de la Reforma Gregoriana también tiene efectos en España. Y, por si fuera poco, la Península sirve de auténtico 'laboratorio' de la idea de cruzada, uno de los fundamentos ideológicos de más importancia dentro de la cristiandad feudal ${ }^{38}$.

36 Vid. Faci Lacasta, «La Reforma Gregoriana», p. 274. Vid. Defourneaux, Les français en Espagne, p. 32 .

37 Vid. García Villoslada, Historia de la Iglesia Católica, II, pp. 338-345. Aquí anota que, el 15 de octubre de 1088, el papa Urbano II expide una bula en la que otorga el palio arzobispal a Bernardo de Toledo y, por primera vez, proclama formalmente los derechos primaciales de la Iglesia toledana sobre todas las Españas. Con esta actuación, y con su favor al rey Alfonso VI, favorecedor de Cluny, titulado «emperador de todas las naciones de Espańa, por la gracia de Dios», se consolida la hegemonía de Castilla, rectora de la reconquista, frente a las aspiraciones de Aragón y Portugal.

38 Vid. Faci Lacasta, «La Reforma Gregoriana», p. 275. 
JOSÉ ANTONIO CALVO GÓMEZ

216

RASGOS DE LA REFORMA DEL CLERO EN LA PENÍNSULA IBÉRICA DURANTE EL SIGLO XI

El profesor Antonio Oliver Monserrat, formado en la Universidad Gregoriana de Roma, donde fue ordenado sacerdote en 1950, estudió sobre todo el caso catalanoaragonés $^{39}$. Aquí explicó la actuación de Alejandro II (1061-1073) y el envío que hizo del cardenal Humberto de Silva Cándida como legado pontificio ante Sancho Ramírez, quien fue a Roma en primavera de 1068 a poner bajo la protección de San Pedro su reino y su persona.

Sin abordar en profundidad los sínodos de Aragón de 1065 y 1067, ni el de Gerona de noviembre de 1068, que presidió el cardenal Humberto y al que asistió Ramón Berenguer I junto a otros obispos y abades del sur de Francia, interesa reseñar, por lo que respecta a este tema, que en sus cánones se contuvieron condenas expresas a los matrimonios incestuosos y a las nupcias posteriores del cónyuge vivo; y también, aunque no especificó casos concretos, al pecado de la simonía y al concubinato de los clérigos.

Como continuación de la actuación pontificia sobre los condados catalanes y sobre las sedes de Provenza y Septimania, de su influencia, el profesor Oliver refirió la actuación del obispo de Gerona Berenguer Guifré (1051-1093) quien, después de intervenir por el bien de la paz y de la Iglesia en las disputas de los dos hijos de Ramón Berenguer I, recibió el encargo del papa de intervenir en el caso del arzobispo de Narbona, que calificó de «endurecido simoníaco». Según se explicó en aquellas líneas, la intervención del gerundense no dio resultado y el arzobispo de Narbona fue depuesto en el sínodo romano de la cuaresma de 1079.

Javier Faci mencionó una nueva actuación de Alejandro II, en este caso por carta al abad del monasterio de San Juan de la Peńa, que fechó en Roma el 17 de octubre de $1071^{40}$. En esta carta, sucinta pero expresiva, se describió la situación del reino de Aragón en consonancia con lo que indicamos para otros lugares. El papa se refirió al envío del legado Humberto para restituir la integridad de la fe cristiana contra los herejes simoníacos y reformar los ritos divinos para adecuarlos a los cánones. También hizo mención a la sujeción del reino y de su rey, Sancho I Ramírez, bajo la protección de San Pedro, miles Sancti Petri, que tuvo lugar, como anotamos, en 1068.

El profesor Faci admitió que "cabe la posibilidad de que se trate de una afirmación de carácter retórico, o que se refiera al contenido global del programa reformador del papado, pero teniendo en cuenta que la carta se dirigía al abad de un monasterio aragonés y a la obra de un personaje concreto, Hugo Cándido, la interpretación más razonable nos lleva a pensar que la iglesia aragonesa atravesaba por una situación semejante y tenía unos

39 Oliver Monserrat, Antonio. «Gregorio VII y Cataluña». En García Villoslada, Historia de la Iglesia en España, II.1 ${ }^{\circ}$, pp. 285-287. El profesor Oliver, ya desaparecido, tiene detrás los trabajos de P. Kehr, ya citados, y las obras de B. Llorca y A. Fliche, que hoy muchos cuestionan, como hemos referido arriba. Vid. además Säвекоw, Gerhard. Die päpstlichen Legationen nach Spanien und Portugal bis zum Ausgang des XII. Jahrhunderts. Berlin: Emil Eberring, 1931.

40 FACI LACASTA, «La Reforma Gregoriana», p. 270, aunque confunde la cita. Vid. PL 146, cols. 13621363: «Instigante nos commissae sancte et universalis Ecclesiae providentia, ad correctionem Ecclesiarum Dei, filium nostrum Hugonem Candidum... in partes illas misimus, qui divina sufragante clementia Christianae fidei robur et integritatem ibi restauravit, Simoniacae haeresis inquinamenta mundavit et confusos ritus divinorum obsequiorum ad regulam canonicam et ordinem reformavit». 
problemas y corrupciones parecidos a los de las demás de la cristiandad occidental, vicios que el papado tenía gran interés en erradicar».

El mismo autor recuperó tres casos más de simonía y nicolaísmo, dos en Castilla y uno en León, que desmontaron la pretensión intelectual de ciertos autores de hacer de la Península Ibérica un espacio libre de los males que aquejaron a la Iglesia en la Plena Edad Media occidental. En los dos primeros siguió los trabajos de Luciano Serrano, que estudió con detalle, en tres volúmenes, la situación del obispado de Burgos a lo largo de toda la Alta y Plena Edad Media ${ }^{41}$.

En 1067, era obispo de Burgos don Simeón, al que algunas fuentes llamaron Gimeno, donde había sido preconizado en $1062^{42}$. Bajo la presidencia del cardenal Humberto de Silva Cándida, legado de Alejandro II, se celebró sínodo en la villa de Nájera, en el marco del cual se realizó una investigación sobre la supuesta condición simoníaca del prelado. El sínodo lo declaró culpable y fue depuesto. Ese mismo año se trasladó al monasterio de Cluny, de donde regresó en 1072 repuesto en su sede ahora por voluntad del propio pontífice.

Dos años después, en 1074, bajo el pontificado de Gregorio VII, tuvo lugar un caso parecido con la deposición del obispo Nunio, de Oca, antigua sede hoy desaparecida, por parte del legado papal Geraldo de Ostia. En carta a Sancho Ramírez, rey de Aragón, y a Alfonso VI, rey de León y Castilla, el mismo papa hizo alusión a esta degradación, que se hizo con su aprobación y pleno conocimiento ${ }^{43}$. Este mismo año de 1074, el obispo Nunio viajó a Roma para solicitar el perdón del papa Hildebrando, de donde vino restituido por el pontífice, sanando de raíz el pecado de simonía, a la antiquam sui episcopatus sedem.

En este punto, sin embargo, Serrano propuso una interpretación diversa, que conectó con un oscuro caso de política eclesiástica ${ }^{44}$. Según este autor, la acusación de simonía pudo haber venido de la mano del propio obispo de Burgos en complicidad con el legado papal con el fin de poder afrontar, sin oposición, la desarticulación de la diócesis de Oca e integrarla, de acuerdo con las disposiciones pontificias, en la jurisdicción de la sede burgalesa. La restitución del obispo Nunio, por lo tanto, no habría tenido lugar en la cátedra de Oca, para entonces ya desaparecida, sino en la de Sasamón, su antigua sede, unida tradicionalmente a Oca, siempre de acuerdo a la opinión de Serrano.

41 Serrano, El obispado de Burgos.

42 Serrano, El obispado de Burgos, vol. I, p. 277.

43 PL 148, cols. 339-340.

44 Serrano, El obispado de Burgos, vol. I, pp. 288-291. El profesor Gonzalo Martínez Díez habla, sin embargo, de un traslado del obispo de Oca a Burgos cincuenta años antes y de la donación, el 8 de junio de 1074, de las infantas Urraca y Elvira de la iglesia de Santa María de Gamonal para que el obispo Jimeno II estableciera en ella la sede episcopal que había sido destruida por los sarracenos en Oca. El año siguiente, en 1075, Alfonso VI habría confirmado este asentamiento del obispo de Burgos, como sucesor histórico de Oca, en Gamonal, para que fuera madre de todas las Iglesias de la región de Castilla: «Elegi in loco abto secundo miliario ab urbe Burgensi, in villa que dicitur Gamonar, ecclesia que dudum ibi fuerat consecrata in honore Sancte Dei Genitricis Marie innovare, et episcopalem catedram in vice Aucensis sedis ibi firmare, ut iuxta decreta canonum mater Ecclesiarum diocesis Castelle iure vocetur». Vid. MARTínez Díez, "La Iglesia de Burgos», pp. 30-31. A partir de 1087, tanto Oca, como los antiguos obispados de Valpuesta, Amaya, Sasamón y Muñó se integran en la sede burgalesa cuyos límites fija Urbano II en 1095 en su carta de confirmación. 


\section{8}

JOSÉ ANTONIO CALVO GÓMEZ

RASGOS DE LA REFORMA DEL CLERO EN LA PENÍNSULA IBÉRICA DURANTE EL SIGLO XI

De ser así, la intervención pontificia en los asuntos eclesiásticos castellanos se habría centrado en la corrección de ciertos vicios, pero también en la remodelación de las sedes de acuerdo con una política de simplificación y centralización en la que estuvieron de acuerdo los propios monarcas. Javier Faci recordó sobre el particular las disposiciones del Dicatus papae de 1075 en las que Gregorio VII se arrogó la potestad de cambiar a voluntad las sedes episcopales.

En 1066, se redactó un documento, que se conserva en la catedral de León, que recogió la aplicación de las disposiciones del concilio de Coyanza ${ }^{45}$. Por este documento, unos monjes de esta sede, ordenados por el obispo Pelayo, se comprometieron a entregar al prelado la tercera parte de los diezmos, que le correspondía, "tam de civaria quam de vino", así como a llevar una vida de acuerdo a su estado: «et non teneamus nobiscum in ipsas ecclesias mulieres extraneas nisi que valuerit matres aut germana sive tia».

Javier Faci, sobre este texto, interpretó que en él se apuntó tanto al cumplimiento de la norma canónica visigoda, contenida en la Hispana, sobre los derechos de los obispos a recibir la tercia de los diezmos y oblaciones de las iglesias, como a la guarda de la castidad y el celibato eclesiásticos, también impuestos por los cánones, que no se cumplirían antes de la celebración del sínodo de Coyanza. Como ahora veremos con más detalle al abordar la materia sobre los sínodos diocesanos, la existencia de una problemática semejante a la de toda la cristiandad hizo que los trabajos de reforma de la vida del clero y la centralización primero episcopal y luego también pontificia, que apareció en el concilio celebrado en Valencia de don Juan en 1055, confluyan inmediatamente con los postulados de los reformadores gregorianos.

En esta reforma, según una interpretación, la celebración del sínodo de Letrán de 1059, solo cuatro años después, representó el primero de los hitos más significativos y la condición de posibilidad, por la independencia con que abordó el papado su propia existencia, del resto de las medidas gregorianas.

\section{LOS SÍNOdOS DE REFORMA DURANTE EL SIGLO XI}

Al abordar la materia sobre la Reforma Gregoriana del clero peninsular, debemos recordar que Ricardo García Villoslada recurrió a la restauración política poco después de «la pesadilla de Almanzor» y a la «nueva sabia inyectada en el tronco nacional por los condes de Castilla y por la dinastía navarra contra el anquilosamiento tradicionalista leonés» para explicar por qué no hayamos de esperar al pontificado de Gregorio VII para descubrir en Espańa los primeros movimientos de restauración eclesiástica y de renovación moral y religiosa ${ }^{46}$.

45 Archivo de la Catedral de León, n. ${ }^{\circ} 1.359$.

46 Vid. García Villoslada, Historia de la Iglesia Católica, II, p. 327. 
Para este autor, los concilios de León (1020), Pamplona (1023), pero sobre todo los de Coyanza ${ }^{47}$ (1055) y Compostela (1056), así como los de Gerona ${ }^{48}$ y Vich (1068), «señalan el progreso de una conciencia cada día más vigilante, con afanes de más perfecta organización y reforma». Andado el tiempo, se refirió Villoslada a dos concilios más, previos a la preconización de Gregorio VII, convocados por el legado de Alejandro II, el cardenal Humberto de Silva Cándida, celebrados en Nájera (1065) y en Llantadilla, junto al Pisuerga (1067). La materia de que se trató parece que corresponde, sin embargo, con el proyecto de unificación en torno al rito romano y con la eliminación del rito mozárabe o toledano, acusado de heterodoxia ${ }^{49}$.

Ciertamente, la celebración de los concilios o sínodos, nacionales o regionales y locales, representó el primero y uno de los instrumentos más importantes en la erradicación de los males que afligían al clero peninsular que, como hemos expuesto, fundamentalmente eran la injerencia de los poderes laicos en la provisión eclesial, o investidura laica, la simonía y el nicolaísmo.

Los concilios estuvieron presentes en la historia de la Península Ibérica desde la época visigoda. Con la recuperación de los territorios del norte y la puesta en marcha de los diversos planes de reforma que, en conjunto, hemos llamado Gregoriana, llegaron a ser agentes fundamentales para su extensión, en concomitancia con la actuación de los legados pontificios, muchos de los cuales intervinieron en su misma convocatoria y celebración ${ }^{50}$.

47 El concilio de Coyanza, celebrado en Valencia de don Juan en 1055, como ya hemos indicado arriba responde más a un modelo de restauración del antiguo orden hispánico y de la pureza de la disciplina visigoda que de reforma. Su estela es seguida inicialmente por los concilios de Santiago del siglo XI; pero, precisamente a raíz de la Reforma Gregoriana, se limita poderosamente su influencia posterior. Vid. García GaLlo, «El concilio de Coyanza», pp. 275-633; ÍDEM, «Las redacciones de los decretos del concilio de Coyanza»; Martínez, Gonzalo. «Concilios nacionales y provinciales». En Aldea Vaquero, Quintín (dir.). Diccionario de historia eclesiástica de España. Madrid: Instituto Enrique Flórez, 1972, vol. I, pp. 537-577; vid. Ferrer, L. «Sínodo». En Aldea Vaquero, Diccionario de historia eclesiástica de España, vol. IV, pp. 2487-2494.

48 Vid. Marqués Planagumà, Josep Maria. «La Iglesia de Gerona». En Martí Bonet, Josep Maria (coord.). Historia de las diócesis españolas. 2, Barcelona, Terrassa, Sant Feliu de Llobregat, Gerona. Madrid: Biblioteca de Autores Cristianos, 2006, pp. 461-686. En esta obra, además del muchas veces mencionado concilio de Gerona de 1068, el autor recoge datos de dos nuevos concilios «gregorianos», celebrados en 1077 y en 1078, con el mismo proyecto de extensión de la reforma. Vid. Villanueva, Jaime. Viage literario a las iglesias de España. Madrid: Real Academia de la Historia, 1850, vol. XIII, pp. 261-264.

49 Vid. Rivera, Juan Francisco. «La controversia adopcionista del siglo vin y la ortodoxia de la liturgia mozárabe». Ephemerides Liturgicae, 1933, vol. 47, pp. 506-536; ÍDEM, "Gregorio VII y la liturgia mozárabe». En este último trabajo, Juan Francisco Rivera menciona la celebración, por este motivo, de un concilio en Leyre, convocado por el propio cardenal legado, en 1067, de otro en Jaca, que no fecha, y de un tercero en Gerona, en 1068. Rivera afirma que la materia principal de estos sínodos corresponde a la renovación litúrgica, en concreto a la sustitución del rito toledano e implantación del romano. En cualquier caso nos darían una nueva muestra del ambiente de reforma que se vive en la Península Ibérica anterior al 1073. Antonio Oliver, como ya hemos indicado, se refiere a los dos concilios celebrados en Aragón en 1065 (¿sería este el de Jaca que menciona Rivera?) y 1067, así como al que tiene lugar en Gerona en 1068, pero en este caso el autor insiste sobre lo que en ellos se trata en relación con la reforma del clero, la condena de la simonía, el concubinato del clero y, también, en lo que a los matrimonios incestuosos y las segundas nupcias del cónyuge vivo se refiere. Vid. Oliver Monserrat, «Gregorio VII y Cataluña», p. 285.

50 Vid. Cowdrey, H. E. J. Pope Gregory VII, 1073-1085. Oxford: Clarendon Press, 1998, donde se analiza el problema de los legados pontificios en la actuación gregoriana y en la imposición de la reforma. 
JOSÉ ANTONIO CALVO GÓMEZ

220

RASGOS DE LA REFORMA DEL CLERO EN LA PENÍNSULA IBÉRICA DURANTE EL SIGLO XI

Como modelo, encontramos el caso de la sede gerundense que estudió con cierta extensión Josep Maria Marqués Planagumà̀ ${ }^{51}$. En este texto, se abordó con suficiente claridad la presencia en Gerona de los principales motivos de reforma que afrontaron los papas del siglo XI, así como la mayor o menor incidencia de los concilios en la extinción de los males del clero, es decir, en la existencia de iglesias propias y la investidura laica, y en los errores de la simonía y el nicolaísmo, que venimos tratando con carácter general.

La colección diplomática de la catedral de Gerona documentó, en el siglo XI, la existencia de numerosas iglesias en manos laicas que pudieron venderse y comprarse, así como someterse al corriente régimen hipotecario ${ }^{52}$. Es verdad, como explicó Marqués Planagumà, que antes de la Reforma Gregoriana algunas de estas «iglesias propias» habían sido «devueltas» por ciertos notables al dominio eclesiástico.

El conde de Barcelona entregó en 1019 las parroquias de Cassà de la Selva y Calonge a la canónica de la catedral. Pero no queda claro, por lo exiguo del caso, si este respondió a un movimiento de reforma general o más bien a una circunstancial entrega de bienes a la Iglesia como otros muchos que llegaban, en concepto de donación en vida y mandas testamentarias, a lo largo de toda la Alta y Plena Edad Media. El propio obispo Pedro Roger, para afrontar los gastos ocasionados por la construcción de la nueva catedral, vendió a su hermana, la condesa Ermesinda, la iglesia parroquial de San Daniel, en la que dijo iba a construir un monasterio femenino. En el testamento de Guillermo Gaufredo, canónigo gerundense, a cuya catedral legó un Fuero juzgo, se anotó la posesión de algunas iglesias, entre otros muchos bienes, cuya administración debió de ocuparle buena parte del tiempo.

Algo parecido debió suceder en el monasterio de Santa María de Lladró, propiedad de los señores Adalberto y Alamburga, que lo habían explotado hasta el punto de que no podía vivir allí ningún clérigo ni se celebraba culto en su iglesia. El de Bañolas había sido destruido y devastado de tal forma que apenas tenía residentes y sus habitaciones estaban ruinosas «por la perversa malicia de los príncipes y prelados y por las incursiones de malvados», anotó el cronista. El mismo conde de Besalú reconoció esta desviación del orden monástico y de la vida regular, como pudo haber acaecido en la abadía de Camprodón, que tiene una laguna histórica entre 1022 y 1096 debida, tal vez, a esta causa.

Josep Maria Marqués mencionó otros ejemplos: «El abadiato de Amer lo obtuvo de 1014 a 1017 un canónigo de la seo de Gerona, posiblemente por compra. Una usurpación de bienes del monasterio de Colera por obra del vizconde de Peralada se produjo en

51 Vid. Marqués Planagumà, «La Iglesia de Gerona». Nos referimos concretamente al capítulo que titula De la Reforma Gregoriana a las primeras sinodales, pp. 499-520. El autor distingue, por razones que no llegamos a entender, entre los «concilios de reforma del 1068 y 1078» y los sínodos diocesanos, que sitúa en lo que denomina "gobierno de la diócesis», que inicia después del IV Concilio de Letrán y su recepción en el sínodo de Lérida de 1229 con las constituciones de Pedro de Castellnou en 1256. Aunque reconoce que cabe la posibilidad de que hubiera otros anteriores, no menciona entre ellos los dos "concilios gregorianos" que ciertamente conoce. Para este tema, vid. MarTí, Ramón. Collecció diplomàtica de la Seu de Girona (8171100). Barcelona: Fundació Noguera, 1997; Noguer i Musqueras, Tomàs y Pons Guri, Josep Maria. «Constitucions sinodals de Girona de la primera compilació». Annals de l'Institut d'Estudis Gironins, 19661967, vol. 18, pp. 49-212.

52 Vid. Martí, Collecció diplomàtica de la Seu de Girona, pp. 265, 275, 280. 
1012. El de Santa María de Rosas lo cedió la condesa Guisla de Empúries a la canónica de Gerona, después de haberlo comprado por 2.000 sueldos a su marido, en 1060».

No todo debe anotarse como negativo en la diócesis de Gerona en el siglo XI. El monasterio de Breda, fundado en 1038, y el de Cervià, en 1053, erigidos por los seńores del lugar, se presentaron como donaciones desinteresadas. Además, para garantizar la observancia regular, los propios fundadores sometieron inmediatamente el cenobio de Cervià al de San Michele di Chiusa, en el Piamonte. Este hecho, que apuntó hacia una nueva sensibilidad, no ocultó todo lo anterior y, por tanto, tampoco anula la necesidad de la reforma, que permaneció muy viva en la mente de los papas gregorianos y de sus legados.

Si la investidura laica y la simonía resultó fácil de documentar en Gerona en el siglo de Gregorio VII, tampoco fue difícil constatar casos de nicolaísmo más o menos velado por las expresiones diplomáticas. En 1064 hizo testamento el caput scholae de la catedral, llamado Poncio. Al igual que el mencionado Guillermo Gaudredo, Poncio legó sus bienes para una obra de la Iglesia, en este caso para la construcción de la canónica de San Martín Sacosta. Pero la relación de tan amplias y dispersas propiedades hace suponer un ejercicio de adquisición, administración y disfrute tan complejo que debió absorber todo el tiempo del clérigo, en cuyo esquema la enseñanza catedralicia se habría visto seriamente afectada, si es que no suprimida. Una curiosa nota necrológica a la muerte del obispo Pedro Roger, en 1050, aseguró que «mereció vida célibe», que solo parece tener sentido si, su consignación, fuera significativa. Josep Maria Marqués anotó que él mismo había estudiado el caso del prior de la canónica de Organyà, de Urgel, que vivía «en estado de matrimonio".

Las noticias sobre clérigos casados en Gerona fueron menos frecuentes que en Urgel, pero no faltaron. Un clérigo casado apareció como propietario de la iglesia de Olives, que más tarde se convirtió en cabildo de canónigos regulares. En el archivo diocesano de Gerona se conserva la noticia, fechada en 1056, de la cesión de un tal Constancio, que dijo ser cabiscol de San Félix de Gerona, del oficio y la dote del mismo a favor de su hijo, Bernardo Constancio ${ }^{53}$.

No se puede concluir que los actores de la Reforma Gregoriana, en Gerona, como en otros lugares, vinieran a ocuparse de un trabajo ya hecho y que, por tanto, su obra resultara, en modo alguno, reiterativa. La celebración de los tres concilios de reforma, que tuvieron lugar en esta tierra en 1068, 1077 y 1078 debió responder con cierta vehemencia a la necesidad que se descubrió desde primera hora en la sede gerundense.

Sobre el concilio de 1068, Marqués afirmó que se celebró bajo la presidencia del cardenal Hugo Cándido, de camino hacia Castilla, donde pretendía terminar con la liturgia mozárabe, según vimos. A él acudieron los obispos de la provincia Narbonense, entre ellos los de Gerona, Urgel y Vic. Y continuó: «En las catorce disposiciones que se publicaron sinodalmente se proscribió la simonía y el matrimonio de los clérigos. Se permitió, con todo, la existencia de clérigos casados, que no podrían pasar más allá del grado de lector. Los eclesiásticos que dejasen las armas serían protegidos por las disposiciones de la paz y tregua de Dios, ya vigentes en la diócesis; los que se negasen a abandonarlas, caerían en excomunión».

53 Archivo Diocesano de Gerona, Archivo de San Feliú, abad, Actes autentichs, n. 37. Para otros ejemplos, vid. Martí, Collecció diplomàtica de la Seu de Girona, p. 214. 
JOSÉ ANTONIO CALVO GÓMEZ

222

RASGOS DE LA REFORMA DEL CLERO EN LA PENÍNSULA IBÉRICA DURANTE EL SIGLO XI

Según parece, por diversas circunstancias que no aclaró Marqués, fue el propio arzobispo de Narbona quien propuso la resistencia al concilio, que no llegó a aplicarse. Tuvieron que pasar casi diez años hasta que un nuevo legado papal, Amado de Oloron, intente una nueva celebración sinodal en Gerona. El arzobispo lo impidió mediante el envío de hombres armados, por lo que tanto el legado como los obispos tuvieron que refugiarse en el condado de Besalú, bajo la protección del conde Bernardo II.

El concilio de Besalú de 1077 no promulgó ningún canon, pero el conde Bernardo, a resultas de lo tratado, depuso a algunos abades de su territorio que habían accedido a su cargo por simonía ${ }^{54}$. En 1078, por fin, se pudo celebrar sínodo en Gerona, bajo la presidencia del propio legado gregoriano, que reiteró «la prohibición de la simonía, del matrimonio de los clérigos, del acceso de los hijos de estos al cargo de sus padres, del uso de armas por parte de los ministros del altar y de los matrimonios entre los parientes próximos». Ramón Martí completó su explicación con las penas que correspondieron a los diversos delitos clericales: «La pena de la simonía sería la nulidad de la ordenación, medida entonces eficaz, pero que la teología posterior había de considerar excesiva. El legado, en cambio, se mostró relativamente tolerante con el dominio de los laicos sobre aquellas iglesias cuya propiedad reivindicaban».

Los monasterios iniciaron un proceso de reforma que pasó, fundamentalmente, por su afiliación a casas religiosas de probada virtud. Así, Camprodón, en 1078, se vinculó a Moissac, filial a su vez del monasterio de Cluny. Cerviá y Cruilles se constituyeron en prioratos de San Michele de Chiusa, ya citado. Sant Pol de Mar se integró en la red de casas de Lérins, y San Pedro de Rodes, en 1090, hizo lo propio en las casas de Tomières. Con la anuencia de los condes de Besalú, a instancias de los legados pontificios Frotardo de Tomières y Ricardo de Marsella, los monasterios de San Pedro de Besalú, en 1071, y Bañolas, en 1081, se unieron al floreciente cenobio de San Víctor de Marsella.

Solo el deseo de los condes de Barcelona de evitar la dispersión que suponían estas relaciones con el extranjero de los monasterios nacionales provocó, a finales de siglo, una cierta vuelta y la creación de una congregación autóctona que inicialmente se centró en San Cugat y luego en el monasterio de Grassa, próximo a Carcasona, regido por el conde de Provenza, un hermanastro del conde Ramón Berenguer III.

Los resultados de la Reforma Gregoriana no fueron definitivos. Marqués Planagumà mencionó la libertad de la iglesia de Santa María de Lladró en 1089, después de su conversión en canónica en $1085^{55}$. Pero fue la única. En general, los diezmos en manos laicas no volvieron a las iglesias, como tampoco los que estaban en poder de monasterios o de la catedral, por lo que creció todavía más la pobreza del clero y de las fábricas.

Además, a pesar de que el obispo en 1117 anatematizó el título de "protector» aplicado a los nobles como eufemismo de su condición de propietarios de las iglesias, la realidad es que siguieron reteniendo sus diezmos como si los concilios gregorianos

54 Antonio Oliver afirma que en esta fecha Frotario, abad de Saint Pons de Thomières, legado de Gregorio VII para la Iglesia de Aragón y Cataluña, que había participado ya en el concilio de Gerona de 1068, aconseja al conde de Besalú que se haga vasallo del papa para favorecer decididamente la reforma de la Iglesia, lo que probablemente responde, también, a ciertos intereses de política internacional. Vid. OLIVER Monserrat, «Gregorio VII y Cataluña», p. 286.

55 Vid. Vayreda i Olivas, Pere. El priorat de Lladó i les seves filials. Barcelona: Imprenta Giro, 1931. 
no hubiesen tenido lugar. En 1095, dos hermanos se repartían las iglesias de Fonolleres, Sedillà y Ullastret; y los casos podrían multiplicarse ${ }^{56}$. Con todo, parece que la tendencia se invirtió después de la actuación gregoriana, en especial después de 1153, en que la Santa Sede promulgó una excomunión general para todos aquellos que detentasen algún derecho sobre las parroquias ${ }^{57}$.

El conde Ramón Berenguer IV dio ejemplo al expresar su compromiso de respetar los bienes de la catedral, San Félix y San Martín de Gerona. La mayoría de los nobles, en los diez ańos siguientes al decreto pontificio, cedieron todas sus prerrogativas, y se reservaron un simple derecho de patronato, como hizo Arnaldo de Llers, en 1160, sobre las nueve iglesias parroquiales de sus feudos de Llers y Cervià ${ }^{58}$.

Los concilios de Gerona en 1068 y en 1078, y de Besalú en 1077, han ocupado buena parte de este apartado. Además resultaron de relevancia ciertamente crecida los concilios y sínodos de Santiago de Compostela ${ }^{59}$; y los de Palencia, donde se celebraron al menos cinco reuniones sinodales antes de la muerte del último papa «gregoriano», Calixto II, en 1124. Concretamente, se celebraron sínodos en 1101, sobre rentas monásticas y catedralicias $^{60} ; 1103$, sobre los clérigos $\operatorname{casados}^{61} ; 1113$, sobre la diócesis de Lugo ${ }^{62} ; 1123$, sobre la diócesis de Zamora ${ }^{63}$; y 1124 , sobre preeminencias diocesanas ${ }^{64}$.

56 Martí, Collecció diplomàtica de la Seu de Girona, p. 459. En 1171 (doc. 324), Arnaldo de Palera renunció a sus vicarías sobre las iglesias de Corçavell, Llerona, Palera, la Cot y Llanars, que las tenía en propiedad. En 1123, cuando el obispo encomienda a Ramón Arnau d'Anglès el castillo de San Sadurní, le cede también la mitad de la propiedad de la iglesia del lugar (doc. 230). En 1128, Pedro Poncio de Torroella recibe la iglesia de Llampaies al servir de corte, hueste y cabalgada al prelado (doc. 144); y Arnaldo Gaufredo, por el mismo concepto, en 1139, se hace propietario de los diezmos de Rupiá (doc. 268).

57 Martí, Collecció diplomàtica de la Seu de Girona, p. 292.

58 Ibidem, p. 305.

59 También cabría haber estudiado con detalle la iglesia de Santiago de Compostela que, en el marco amplio de la Reforma Gregoriana, celebra sínodo en 1056 (provincial), 1114 (dos, uno diocesano y otro provincial), 1121, 1122, 1124 (dos, uno en marzo y otro en abril) y 1125. Vid. Barreiro Fernández, José Ramón. "Concilios provinciales compostelanos». Compostellanum, 1970, vol. 15, pp. 534-541; DíAZ Y DíAz, Manuel C. «La diócesis de Iria-Compostela hasta 1100». En García Oro, José (coord.). Historia de las diócesis españolas. 14, Iglesias de Santiago de Compostela y Tuy-Vigo. Madrid: Biblioteca de Autores Cristianos, 2002, pp. 9-40; García Oro, José. «La diócesis de Compostela en el régimen de cristiandad (1100-1550). De Gelmírez a Fonseca». En García Oro, Historia de las diócesis españolas. 14, pp. 41-175.

60 En diciembre de 1101, en el concilio legatino de Palencia, presidido por el cardenal Ricardo, abad de San Víctor de Marsella, se dota la mesa del cabildo de Palencia y se discute sobre el pago de la pontificia de los monasterios. Vid. Egido, Teófanes (coord.). Historia de las diócesis españolas. 19, Iglesias de Palencia, Valladolid y Segovia. Madrid: Biblioteca de Autores Cristianos, 2004, p. 227.

61 En enero de 1103, en el concilio legatino de Carrión, presidido por el arzobispo Bernardo de Toledo, se trata sobre los sacerdotes casados antes de la Reforma Gregoriana, la suspensión de los monasterios dúplices y la erección de la sede episcopal de Salamanca. Vid. EgIdo, Historia de las diócesis españolas. 19, p. 227.

62 El 25 de octubre de 1113, en el concilio legatino de Palencia, presidido por el arzobispo Bernardo de Toledo, se provee de obispo a Lugo y se traslada la sede de Mondoñedo. Vid. EgIDo, Historia de las diócesis españolas. 19, p. 227.

63 En 1123, en el concilio legatino de Valladolid, presidido por el cardenal legado Diosdado, se discute la adscripción de la diócesis de Zamora a las provincias de Toledo, Braga o Compostela. Vid. EGIDo, Historia de las diócesis españolas. 19, p. 227.

64 En el concilio de Valladolid, diócesis de Palencia, bajo la presidencia del cardenal legado Diosdado, se aborda la cuestión de la preeminencia entre Toledo y Santiago. Vid. EGIDo, Historia de las diócesis españolas. 19 , p. 376. 


\section{4}

JOSÉ ANTONIO CALVO GÓMEZ

RASGOS DE LA REFORMA DEL CLERO EN LA PENÍNSULA IBÉRICA DURANTE EL SIGLO XI

Antes de la muerte de Gregorio VII, destacó la celebración del concilio nacional del reino de León, en Burgos, en 1080, estudiado por Fidel Fita ${ }^{65}$; y el concilio de Husillos de 1088, en el que se depuso a Diego Peláez, obispo de Compostela, y se fijó el límite meridional diocesano de Burgos ${ }^{66}$.

Javier Faci trató de hacer un balance de los resultados de la acción reformadora en las Iglesias peninsulares durante todos estos años ${ }^{67}$. Este autor pensó, fundamentalmente, que fue parecido al de otros reinos cristianos occidentales: «se refrenan algunos abusos, los más evidentes y espectaculares, pero sin que, en ningún caso, se llegue a esa pureza e independencia completa del estado eclesiástico preconizadas por los reformistas externos».

Por este motivo, por el hecho de que hubiera sido imposible conseguir una total separación entre los aspectos temporales y la dimensión espiritual en el contexto de una sociedad de conformación feudal, al profesor Faci no le resultó sorprendente el contenido de los cánones del concilio nacional de Burgos de 1117, en que se insistió en la defensa de la jurisdicción eclesiástica ${ }^{68}$. Este concilio, presidido por el cardenal Bosón, legado de Pascual II, hizo una somera descripción de la Iglesia castellana al terminar el primer periodo de la Reforma Gregoriana. Entre las prohibiciones que redactó, destacó el canon número cinco en el que se condenó la enajenación a los laicos de los vasos sagrados de las iglesias: «in feodum, quod in Ispania prestimonium vocant ${ }^{69}$.

Este texto resulta importante por varias razones. En primer lugar, porque, a diferencia de lo propugnado por autores como Menéndez Pidal, constata la presencia de ciertos abusos en las Iglesias peninsulares después del periodo de reforma. Si la actuación gregoriana fue importante en la Península Ibérica, no lo fueron menos las resistencias sociales y eclesiásticas para hacerla efectiva, que ocuparon, todavía, buena parte de la Baja Edad Media.

Además, en respuesta a quienes negaron la presencia de instituciones de tipo feudal en esta tierra, hace una lectura del hecho verdaderamente significativa en un momento en

65 En la primavera del año 1080, se reúne sínodo en Burgos con asistencia de los obispos de Compostela, Burgos, Mondoñedo, Tuy, Lugo, León, Palencia, Orense, Coimbra, Oviedo, Astorga, Calahorra y Álava. Preside el cardenal legado Ricardo, abad de San Víctor de Marsella. En él se aprueba la implantación definitiva del rito romano y abandono del visigodo. Además, se dictaron algunas medidas a favor del celibato eclesiástico. Vid. Martínez Díez, «La Iglesia de Burgos», p. 44; Fita, Fidel. «El concilio nacional de Burgos de 1080». Boletín de la Real Academia de la Historia, 1906, vol. 49, pp. 337-384.

66 Sínodo celebrado en Husillos, a 9 kilómetros al norte de Palencia, presidido por el rey Alfonso VI y por el legado pontificio, cardenal Ricardo, abad de San Víctor de Marsella, con asistencia de los arzobispos de Toledo y de Aix, en Francia, y los obispos de Burgos, Tuy, Oviedo, Astorga, Palencia, León, Compostela, Coimbra, Nájera y Orense. Se fijan los límites de Burgos con la diócesis de Osma, todavía no restaurada, a la espera de la restitución posterior de Sigüenza y Segovia, que también sucumben tras la invasión del 711 . Vid. Martínez Diez, «La Iglesia de Burgos», pp. 35-37.

67 Vid. Faci Lacasta, «La Reforma Gregoriana», pp. 271-272.

68 Concilio legatino de once obispos de España y Portugal en defensa de la jurisdicción eclesiástica y condena de los matrimonios consanguíneos. Vid. Bartolomé Martínez, Historia de las diócesis españolas. 20 , p. 316.

69 Vid. Fita, Fidel. «El concilio nacional de Burgos (18 de febrero de 1117)». Boletín de la Real Academia de la Historia, 1906, vol. 48, pp. 387-407. 
el que la influencia de las ideas ultrapirenaicas fue mayor. Al concepto de feudo, extraño en la tradición hispana, se le identificó con otra institución equivalente, que se llamaba prestimonio $^{70}$.

Estas realidades, económicas y sociales, de orden semejante, subyacieron a una institucionalización feudal diversa ${ }^{71}$, que progresivamente se fue equiparando a la europea del momento, aplicadas, como en los demás estados europeos, al mismo orden de la Iglesia occidental.

Francisco Javier Fernández Conde hizo su propia valoración del resultado de la Reforma Gregoriana en la Península Ibérica a la luz de la celebración de los concilios generales y sínodos diocesanos durante los primeros años del siglo XII ${ }^{72}$. Este autor citó en primer lugar la celebración de una serie de asambleas sinodales fundamentalmente de orden político, que tuvieron como finalidad principal la solución de la nueva coyuntura creada en la Península Ibérica a raíz de la toma de Toledo en 1085 y sus pretensiones jerárquicas sobre el resto de las diócesis sufragáneas, así como la delimitación de los nuevos territorios diocesanos tras el avance repoblador de los ejércitos castellano-leoneses y, en menor medida, también aragoneses, donde los problemas surgen fundamentalmente entre los monasterios con jurisdicción sobre territorios y personas. Las referencias a la Reforma Gregoriana quedaron muy matizadas en este primer grupo de concilios ${ }^{73}$.

Tampoco existió una clara relación entre los postulados gregorianos y otro número más o menos significativo de concilios en los que se afrontó la situación creada a la muerte del rey Alfonso VI y el ascenso al trono de su hija dońa Urraca (1109-1126). La muerte de su esposo, Raimundo de Borgoña, en 1107, precipitó una serie de intervenciones episcopales que pretendieron asegurar la estabilidad del reino y los derechos del príncipe don Alfonso (futuro Alfonso VII, el Emperador) cuando la reina decidió volver a casarse, en segundas nupcias, con Alfonso I de Aragón, el Batallador ${ }^{74}$.

Los legados pontificios presidieron muchos de estos concilios, enviados a la Península para dirimir las cuestiones más graves que se trataron. Sin embargo, la valoración

70 Vid. García de Valdeavellano, Luis. «El prestimonio: contribución al estudio de las manifestaciones del feudalismo en los reinos de León y Castilla durante la Edad Media». Anuario de Historia del Derecho Español, 1955, vol. 25, pp. 5-122; GARcía-Gallo, Alfonso. Las instituciones sociales en España en la Alta Edad Media (siglos VIII-XII); y El hombre y la tierra en la Edad Media leonesa: el prestimonio agrario. Barcelona: El Albir, 1981.

71 Desde otros presupuestos, Faci dice aquí «insuficiente».

72 Vid. Fernández Conde, Francisco Javier. «Los concilios de la época posgregoriana. La reforma del clero secular y de las instituciones pastorales». En García Villoslada, Historia de la Iglesia en España. II.1. ${ }^{\circ}$, pp. 426-441; Ídem. La religiosidad medieval en España: Plena Edad Media (siglos XI-XII). Gijón: Trea-Oviedo: Ediuno, 2005; vid. MarTíNEz, «Concilios nacionales y provinciales», pp. 537-577.

73 En este primer grupo se pueden incluir los concilios de Palencia de 1100, de Segovia de 1118, los de Santiago a partir de 1120, de León de 1134, de Valladolid, Tarragona y Calahorra de 1155, de Barcelona de 1168 y de Tarragona de 1170 .

74 En este contexto pueden situarse los concilios de León de 1107 y 1114, en que se declara nulo el matrimonio entre consanguíneos, pensando en el matrimonio de la reina; el de Palencia de 1113; el de Burgos, ya citado, de 1117, que precisa el impedimento de consanguinidad hasta el séptimo grado; y el de Santiago, de 1125, presidido por el arzobispo Gelmírez. En el concilio de León de 1135, finalmente, Alfonso VII fue proclamado emperador. En torno a una problemática parecida, ahora con el matrimonio de Alfonso IX y Teresa de Portugal, tienen lugar los concilios celebrados en Salamanca en 1191 y 1192. 
que hizo el profesor Fernández Conde fue clara: «Ni el valor personal indiscutible de los representantes pontificios ni la asiduidad de las asambleas episcopales consiguieron dar un impulso decisivo a la reforma, cuya temática ya no ocupa en el conjunto de los concilios del siglo XII el mismo lugar preferente que en los de la segunda parte de la centuria anterior" ${ }^{75}$.

La celebración de los concilios de Letrán I (1123) y II (1139) pudo estar detrás de una cierta revitalización de los postulados gregorianos, el rigor de cuyos reformadores, en lo que al clero se refería, parecía haberse quedado verdaderamente relegado. En un momento de consolidación señorial, siguieron presentes los abusos contra bienes, derechos o personas eclesiásticas ${ }^{76}$; las intromisiones de los laicos en asuntos de Iglesia; y las iglesias propias $^{77}$; y tampoco había desaparecido el concubinato clerical ${ }^{78}$ ni la simonía, que se volvieron a tratar con mayor frecuencia en los sínodos que siguieron. Los concilios de Lérida de 1155 y 1173, por ejemplo, no hicieron sino repetir la doctrina de la Iglesia sobre la incontinencia del clero y la recepción en manos laicas de órdenes o beneficios eclesiásticos ${ }^{79}$.

Fernández Conde no se mostró optimista al tratar de resumir el resultado de toda esta etapa y las nuevas circunstancias de los concilios de los últimos decenios del siglo XII.

75 Vid. Fernández Conde, «Los concilios de la época posgregoriana», p. 431.

76 Desde principios de siglo, encontramos condenas canónicas de los señores laicos que atenten contra los bienes y personas eclesiásticas. A este propósito responde el introito del concilio de León de 1114, en el que se prohíbe la violencia de los legos «en las iglesias de Dios, en sus cosas y en sus ministros», además de ordenar la debida restitución de todo cuanto estos hubieren detraído injustamente. Juan Tejada recoge, en el mismo sentido, los cánones 21, 22 y 23 del concilio de Lérida de 1173. Vid. Tejada y Ramiro, Juan. Colección de cánones y de todos los concilios de la Iglesia de España y de América. Vol. 3 (811-1429). Madrid: Santa Coloma y Peña, 1861, p. 285.

77 Allí especifica que el concilio de Palencia de 1129 «ordena taxativamente que nadie posea de forma hereditaria iglesias o lo que está ochenta y cuatro pasos alrededor de las mismas", prohíbe que se entreguen en préstamo o arrendamiento a laicos y, para salvaguardar la autonomía jurisdiccional de los obispos, prescribe que «los clérigos no reciban las iglesias de mano de los señores seculares y que los vicarios de los obispos no lo permitan» En el mismo orden se sitúan los concilios de Lérida de 1155 y 1173 . Vid. Tejada y Ramiro, Colección de cánones, pp. 257-258.

78 Fernández Conde afirma que «los decretos contra el concubinato de los clérigos, tan característicos de las asambleas inspiradas por los reformadores gregorianos, no parece se tomaran demasiado en serio». Vid. FERnÁNDEZ Conde, «Los concilios de la época posgregoriana», p. 432. Él mismo repasa el trabajo de Tejada y Ramiro sobre esta temática. Aquí anota que el concilio de Carrión de 1103 trata de regular la situación jurídica de los eclesiásticos casados antes de la legislación romana que vetaba estos matrimonios; el de León de 1114, recuperando la legislación de la Iglesia sobre el particular, establece que ningún clérigo tuviera en casa otras mujeres que las permitidas por los cánones, es decir, parientes muy cercanas; y el de Palencia de 1129 obliga a que las mancebas de los clérigos sean arrojadas públicamente de las iglesias.

79 En el concilio de Lérida de 1155 se dice: «Con arreglo a lo dispuesto por los sumos pontífices León IX, Nicolás II, Calixto I e Inocencio II acerca de la continencia del clero, sepárese de sus mujeres a los ordenados in sacris y a los monjes profesos que hubiesen contraído matrimonio, por no ser éste válido... y los clérigos... concubinarios públicos..., que amonestados por su obispo u otro prelado no se corrijan dentro de cuarenta días y hagan la debida penitencia, sean privados de su oficio y beneficio. Prohíbase oír la misa y el evangelio del presbítero o diácono cuya incontinencia es notoria». Vid. Tejada y Ramiro, Colección de cánones, 279. Añade Fernández Conde que este precepto, como aquel en que, en 1173, se condena a los que recibiesen "per manum laicam» órdenes o beneficios eclesiásticos, «debieron de encontrar un eco muy escaso en la mayoría de los ambientes de la Iglesia hispana». 
En un momento de su discurso, afirmó que «todo hace pensar que concilios típicamente gregorianos como el de Besalú (1077), donde se había excomulgado por delitos de simonía al arzobispo Wifredo de Narbona y a seis abades de monasterios pirenaicos, o el de Gerona (1078), en el que Amado de Oloron, legado de Gregorio VII, anatematizaba el nicolaísmo y la simonía y tomaba partido por el sector más radical de los reformistas, declarando inválidas las ordenaciones de los clérigos que hubieran incurrido en el pecado de Simón Mago, eran ya pura historia». Y continuó: «La larga serie de concilios posgregorianos celebrados en España apenas se ocupó de las instituciones propias del clero secular o de las estrictamente pastorales. Se echa de menos en ellos, por ejemplo, la redacción de normas relacionadas con el régimen y estilo de la vida de los canónigos seculares, justamente en una época crucial para esta forma de congregaciones eclesiásticas» ${ }^{80}$.

\section{Conclusión}

Los resultados de la Reforma Gregoriana no fueron definitivos. Como hemos indicado, en general, los diezmos en manos laicas no volvieron a las iglesias, como tampoco los que estaban en poder de monasterios o de la catedral, por lo que aumentó todavía más la pobreza del clero y de las fábricas. A pesar de los anatemas lanzados sobre el título de «protector» aplicado a los nobles como eufemismo de su condición de propietarios de las iglesias, la realidad fue que siguieron reteniendo sus diezmos como si los concilios no hubiesen tenido lugar. Parece que la tendencia se invirtió solo después de 1153, en que la Santa Sede promulgó una excomunión general para todos aquellos que detentasen algún derecho sobre las parroquias.

La Reforma, que vino de la mano de los legados pontificios de la primera hora y se materializó en las diversas asambleas sinodales más o menos radicales en planteamientos y resultados, así como en nuevos ordenamientos litúrgicos y canónicos, necesitó todavía algunos ańos de paciente desarrollo en la vida de la Iglesia peninsular: en su legislación y estructuras, pero también en la conciencia de los pastores y de los fieles, comprometidos con esta reforma no menos que lastrados por una historia personal y comunitaria excesivamente grande.

A pesar de las dificultades de implantación de sus proyectos, no cabe minimizar la importancia de la Reforma Gregoriana en la Península Ibérica. Se ha ido viendo que los problemas que plantearon las Iglesias peninsulares eran semejantes a los del resto de Europa y, por tanto, también las soluciones se asemejaron. También se ha podido apreciar que Espańa no quedó fuera de los planes hegemónicos del pontificado, sino que ocupó en ellos un papel muy importante. La reorganización eclesiástica que experimentó la cristiandad como consecuencia de la Reforma Gregoriana también tuvo efectos en Espańa. Y, por si fuera poco, la Península sirvió de auténtico «laboratorio» de la idea de cruzada, uno de los fundamentos ideológicos más importantes de la cristiandad feudal.

80 Vid. Fernández Conde, «Los concilios de la época posgregoriana», pp. 433-441; Tejada y Ramiro, Colección de cánones, pp. 136-138 (Besalú) y 138-141 (Gerona). 
JOSÉ ANTONIO CALVO GÓMEZ

RASGOS DE LA REFORMA DEL CLERO EN LA PENÍNSULA IBÉRICA DURANTE EL SIGLO XI

REFERENCIAS BIBLIOGRÁFICAS

Álvarez Borge, Ignacio. Monarquia feudal y organización territorial. Alfoces y merindades en Castilla (siglos X-XIV). Madrid: Consejo Superior de Investigaciones Científicas, 1993.

Arquillière, Henri-Xavier. Saint Gregoire VII. Essai sur sa conception du pouvoir pontifical. Paris: Librairie Philosophique J. Vrin, 1934.

Barreiro Fernández, José Ramón. «Concilios provinciales compostelanos». Compostellanum, 1970, vol. 15, pp. 534-541.

Barrios García, Ángel. «Conquista y repoblación: el proceso de reconstrucción del poblamiento y el aumento demográfico». En Barrios García, Ángel (coord.). Historia de Ávila II. Edad Media (siglos VIII-XIII). Ávila: Institución Gran Duque de Alba, 2000, pp. 227-270.

Barrios García, Ángel. «Del Duero a Sierra Morena: estructura y expansión del feudalismo medieval castellano». En Maíllo Salgado, Felipe (ed.). España, Al-Andalus, Sefarad: sintesis y nuevas perspectivas. Salamanca: Ediciones Universidad de Salamanca, 1988, pp. 37-48.

Barrios García, Ángel. «La formación del feudalismo en la Península Ibérica». En Romanización y reconquista en la Península Ibérica: nuevas perspectivas. Salamanca: Ediciones Universidad de Salamanca, 1998, pp. 11-24.

Barrios García, Ángel. «Repoblación de la zona meridional del Duero. Fases de ocupación, procedencias y distribución espacial de los grupos repobladores». Studia Historica. Historia Medieval, 1985, vol. 3, pp. 33-82.

Barrios García, Ángel. «Repoblación y colonización: la dinámica de creación de paisajes y el crecimiento económico». En Barrios García, Ángel (coord.). Historia de Ávila II. Edad Media (siglos VIII-XIII). Ávila: Institución Gran Duque de Alba, 2000, pp. 271-336.

Barrios García, Ángel. «Repoblación y feudalismo en las Extremaduras». En En torno al feudalismo hispánico. I Congreso de estudios medievales, pp. 417-433.

Barrios García, Ángel. «Romanización y reconquista en la Península Ibérica: nuevas perspectivas». Cassiodorus, 1997, vol. 3, pp. 147-152.

Bidagor, Ramón. La «iglesia propia» en España. Estudio histórico-crítico. Romae: apud aedes Pontificiae Universitatis Gregorianae, 1933.

Calvo Gómez, José Antonio. «Aproximación a la historia de los clérigos regulares de san Agustín en la Península Ibérica». Religión y Cultura, 2009, vol. 251, pp. 829-874.

Calvo Gómez, José Antonio. «El reiterado conflicto sobre la jurisdicción eclesiástica entre el obispo de Ávila y el abad de Santa María de Burgohondo (siglos XI-XIx)». Anthologica Annua, 2004-2005, vol. 51-52, pp. 247-434.

Calvo Gómez, José Antonio. "Los clérigos regulares de san Agustín en la Edad Media: un intento de conceptualización». Religión y Cultura, 2009, vol. 248, pp. 145-180.

Calzada, Luciano de la. «La proyección del pensamiento de Gregorio VII en los reinos de Castilla y León». Studi Gregoriani, 1948, vol. 3, pp. 1-87.

Casa Martínez, Carlos de la. «Despoblación y repoblación de los Extrema Durii». En Repoblación y reconquista. Actas del III Curso de cultura medieval. Aguilar de Campoo: Centro de Estudios del Románico, 1993, pp. 89-94.

Catalán Martínez, Elena. "El derecho de patronato y el régimen beneficial de la Iglesia española en la Edad Moderna». Hispania Sacra, 2004, vol. 56, pp. 135-167.

Cowdrey, H. E. J. Pope Gregory VII, 1073-1085. Oxford: Clarendon Press, 1998.

Defourneaux, Marcelin. Les français en Espagne aux XI et XII siècles. Paris: Presses Universitaires de France, 1949. 
JOSÉ ANTONIO CALVO GÓMEZ

RASGOS DE LA REFORMA DEL CLERO EN LA PENÍNSULA IBÉRICA DURANTE EL SIGLO XI

Díaz y Díaz, Manuel C. «La diócesis de Iria-Compostela hasta 1100». En García Oro, José (coord.). Historia de las diócesis españolas. 14, Iglesias de Santiago de Compostela y Tuy-Vigo. Madrid: Biblioteca de Autores Cristianos, 2002, pp. 9-40.

Dopsch, Alfons. Fundamentos económicos y sociales de la cultura europea. De César a Carlomagno. Madrid: Fondo de Cultura Económica, 1951.

Durán Gudiol, Antonio. «La Iglesia en Aragón durante el siglo XI». En Estudios de Edad Media de la Corona de Aragón, IV. Zaragoza: Escuela de Estudios Medievales, 1951, pp. 7-68.

Egido, Teófanes (coord.). Historia de las diócesis españolas. 19, Iglesias de Palencia, Valladolid y Segovia. Madrid: Biblioteca de Autores Cristianos, 2004.

En torno al feudalismo hispánico. I Congreso de estudios medievales. Ávila: Fundación Sánchez-Albornoz, 1989.

Estepa Díez, Carlos. El reinado de Alfonso VI. Madrid: Spainfo Ings, 1985.

FACi Lacasta, Javier. «La iglesia propia en España». En García Villoslada, Ricardo (dir.). Historia de la Iglesia en España, II. $1^{\circ}$. La Iglesia en la España de los siglos VIII al XIV. Madrid: Editorial Católica, 1982, pp. 136-139.

FaCi Lacasta, Javier. «La Reforma Gregoriana en Castilla y León». En García Villoslada, Ricardo (dir.). Historia de la Iglesia en España, II.1 ${ }^{\circ}$. La Iglesia en la España de los siglos VIII al XIV. Madrid: Editorial Católica, 1982, pp. 262-275.

Fernández Conde, Francisco Javier. «Los concilios de la época posgregoriana. La reforma del clero secular y de las instituciones pastorales». En García Villoslada, Ricardo (dir.). Historia de la Iglesia en España, II.1 ${ }^{\circ}$. La Iglesia en la España de los siglos VIII al XIV. Madrid: Editorial Católica, 1982, pp. 426-441.

Fernández Conde, Francisco Javier. La religiosidad medieval en España: Plena Edad Media (siglos XI-XII). Gijón: Trea-Oviedo: Ediuno, 2005.

Ferrer, L. «Sínodo». En Aldea Vaquero, Quintín (dir.). Diccionario de historia eclesiástica de España. Madrid: Instituto Enrique Flórez, 1972, vol. IV, pp. 2487-2494.

Fita, Fidel. «El concilio nacional de Burgos (18 de febrero de 1117)». Boletín de la Real Academia de la Historia, 1906, vol. 48, pp. 387-407.

Fita, Fidel. «El concilio nacional de Burgos de 1080». Boletín de la Real Academia de la Historia, 1906, vol. 49, pp. 337-384.

FrazÃo da Silva, Andréia Cristina Lopes. "A Reforma Gregoriana e o Bispado de Santiago de Compostela segundo a História Compostelana». Anuario Brasileño de Estudios Hispánicos, 2000, vol. 10, pp. 217-232.

Fustel de Coulanges, Numa Denis. Histoire des institutions de l'ancienne France. Paris: Librairie Hachette, 1874.

Fustel de Coulanges, Numa Denis. La cité antique. Paris: Durand, 1864.

Fustel de Coulanges, Numa Denis. Recherches sur quelques problèmes d'histoire. Paris: Librairie Hachette, 1885.

Gambra, Andrés. Alfonso VI. Cancillería, curia e imperio. León: Centro de Estudios e Investigación San Isidoro, 1997-1998, 2 vols.

García de Valdeavellano, Luis. «El prestimonio: contribución al estudio de las manifestaciones del feudalismo en los reinos de León y Castilla durante la Edad Media». Anuario de Historia del Derecho Español, 1955, vol. 25, pp. 5-122.

García Gallo, Alfonso. «El concilio de Coyanza. Contribución al estudio del derecho canónico español en la Alta Edad Media». Anuario de Historia del Derecho Español, 1950, vol. 20, pp. 275-633. 
JOSÉ ANTONIO CALVO GÓMEZ

RASGOS DE LA REFORMA DEL CLERO EN LA PENÍNSULA IBÉRICA DURANTE EL SIGLO XI

García Gallo, Alfonso. «Las redacciones de los decretos del concilio de Coyanza». Archivos Leoneses, 1951, vol. 9, pp. 25-39.

García Oro, José. «La diócesis de Compostela en el régimen de cristiandad (1100-1550). De Gelmírez a Fonseca». En García Oro, José (coord.). Historia de las diócesis españolas. 14, Iglesias de Santiago de Compostela y Tuy-Vigo. Madrid: Biblioteca de Autores Cristianos, 2002, pp. 41-175.

García Villada, Zacarías. Organización y fisonomía de la Iglesia española desde la caída del Imperio visigodo en 711, hasta la toma de Toledo en 1085. Madrid: [s. n.], 1935.

García Villoslada, Ricardo. Historia de la Iglesia Católica. II, Edad Media (800-1303). Madrid: Editorial Católica, 1958.

García-Gallo, Alfonso. Las instituciones sociales en España en la Alta Edad Media (siglos VIII-XII); y El hombre y la tierra en la Edad Media leonesa: el prestimonio agrario. Barcelona: El Albir, 1981.

Garzón Pareja, Manuel. Diezmos y tributos del clero de Granada. Granada: Archivo de la Real Chancillería, 1974.

GonzÁlez, Julio. «La Extremadura castellana al mediar el siglo xiII». Hispania, 1974, vol. 127, pp. 265-424.

GonZÁLEz, Julio. «La repoblación de la Extremadura leonesa». Hispania, 1943, vol. 11, pp. 195273.

GoÑı Gaztambide, José. «Gregorio VII». En Gran enciclopedia Rialp. Madrid: Rialp, 1984, vol. XI, pp. 324-327.

Goñı Gaztambide, José. Historia de la Bula de la Cruzada en España. Vitoria: Editorial del Seminario, 1958.

Guijarro González, Susana. «Las escuelas y la formación del clero de las catedrales en las diócesis castellano-leonesas (siglos XI al Xv)». En Iglesia Duarte, José Ignacio de la (coord.). La enseñanza en la Edad Media. X Semana de Estudios Medievales de Nájera. Logrońo: Instituto de Estudios Riojanos, 2000, pp. 61-96.

Herlihy, David. "Church property on the European Continent». Speculum, 1961, vol. 36, pp. 81-102.

Kenr, Paul. "Cómo y cuándo se hizo Aragón feudatario de la Santa Sede (estudio diplomático)». En Estudios de Edad Media de la Corona de Aragón, I. Zaragoza: Escuela de Estudios Medievales, 1945, pp. 285-326.

Kenr, Paul. Das papsttum und die Königreiche Navarra und Aragon bis zur Mitte des XII. Jarhunderts. Berlin: Akademie der Wissenschaften, 1928.

KeHr, Paul. Wie und wann wurde das Reich Aragon ein Lehen der römischen Kirche? Berlin: Akademie der Wissenschaften, 1928.

Llorca, Bernardino. «Derechos de la Santa Sede sobre España. El pensamiento de Gregorio VII». En Fliche, Augustin y Martin, Victor. Historia de la Iglesia. VIII, Reforma Gregoriana y reconquista. Valencia: Edicep, 1976, pp. 551-575.

Mansi, Giovan Domenico. Sacrorum Conciliorum nova et amplissima collectio. Graz: Akademische Druck- u. Verlagsanstalt, 1961.

Mansilla, Demetrio. La curia romana y el reino de Castilla en un momento decisivo de su historia (1061-1085). Burgos: Seminario Metropolitano, 1944.

Marqués Planagumà, Josep Maria. «La Iglesia de Gerona». En Martí Bonet, Josep Maria (coord.). Historia de las diócesis españolas. 2, Barcelona, Terrassa, Sant Feliu de Llobregat, Gerona. Madrid: Biblioteca de Autores Cristianos, 2006, pp. 461-686. 
JOSÉ ANTONIO CALVO GÓMEZ

RASGOS DE LA REFORMA DEL CLERO EN LA PENÍNSULA IBÉRICA DURANTE EL SIGLO XI

Martí Bonet, Josep Maria. «Sant Oleguer i l'aplicació de la Reforma Gregoriana». Acta Sacra Tarraconensia, 1998, vol. 71, pp. 537-579.

MarTí, Ramón. Collecció diplomàtica de la Seu de Girona (817-1100). Barcelona: Fundació Noguera, 1997.

Martín Martín, José Luis. «Beneficios y oficios del clero rural castellano (siglos XIII-Xv)». Anuario de Estudios Medievales, 2005, vol. 35, pp. 693-736.

Martín Martín, José Luis. «El clero rural en la Corona de Castila». En Martínez San Pedro, María de los Desamparados y Segura del Pino, Dolores. La Iglesia en el mundo medieval y moderno. Almería: Instituto de Estudios Almerienses, 2004, pp. 55-82.

Martín Martín, José Luis. «El poder de los canónigos medievales». Historia 16, 1981, vol. 61, pp. 55- 60.

MarTín Viso, Ińaki. "Capere vel populare. Formación y desarrollo de una frontera feudal entre el Duero y el Tajo (siglos XI- XIII)». En SABATÉ, Flocel (ed.). Balaguer 1105. Cruillla de civilitzacions. Lleida: Pagès, 2007, pp. 177-223.

Martínez Díez, Gonzalo. «La Iglesia de Burgos. Desde la invasión musulmana hasta el traslado de la sede de Oca a Burgos: 711-1081». En Bartolomé Martínez, Bernabé (coord.). Historia de las diócesis españolas. 20, Iglesias de Burgos, Osma-Soria y Santander. Madrid: Biblioteca de Autores Cristianos, 2004, pp. 13-41.

Martínez, Gonzalo. "Concilios nacionales y provinciales». En Aldea Vaquero, Quintín (dir.). Diccionario de historia eclesiástica de España. Madrid: Instituto Enrique Flórez, 1972, vol. I, pp. 537-577.

Menéndez Pidal, Ramón. «Repoblación y tradición en la cuenca del Duero». En Enciclopedia lingüistica hispánica. Madrid: Consejo Superior de Investigaciones Científicas, 1960.

Menéndez Pidal, Ramón. La España del Cid. 6. a ed. Madrid: Espasa-Calpe, 1967.

Mínguez Fernández, José María y Ser Quijano, Gregorio del (coords.). La Península en la Edad Media: treinta años después. Estudios dedicados a José-Luis Martín. Salamanca: Ediciones Universidad de Salamanca, 2006.

Mínguez Fernández, José María. Alfonso VI: poder, expansión y reorganización interior. Hondarribia: Nerea, 2000.

Moráis Morán, José Alberto. «Nuevas reflexiones para la lectura iconográfica de la Portada del Perdón de San Isidoro de León: el impacto de la Reforma Gregoriana y el arte de la tardoantigüedad». De Arte: Revista de Historia del Arte, 2006, vol. 5, pp. 63-86.

Morghen, Raffaello. Gregorio VII. Torino: Unione Tipografico-Editrice Torinese, 1942.

Moxó y Ortiz de Villajos, Salvador de. Repoblación y sociedad en la España cristiana medieval. Madrid: Rialp, 1979.

Nieto Soria, José Manuel y SAnz SAncho, Iluminado. La época medieval: Iglesia y cultura. Madrid: Istmo, 2001.

Noguer i Musqueras, Tomàs y Pons Guri, Josep Maria. «Constitucions sinodals de Girona de la primera compilació». Annals de l'Institut d'Estudis Gironins, 1966-1967, vol. 18, pp. 49-212.

Oliver Monserrat, Antonio. «Gregorio VII y Cataluña». En García Villoslada, Ricardo (dir.). Historia de la Iglesia en España, II.1 ${ }^{\circ}$. La Iglesia en la España de los siglos VIII al XIV. Madrid: Editorial Católica, 1982, pp. 285-287.

OrLANDIS, José. «Reforma eclesiástica en los siglos XI y XII». En La Iglesia en la España visigótica y medieval. Pamplona: Ediciones Universidad de Navarra, 1976, pp. 309-343.

Palacios Martín, Bonifacio. «Castilla, Cluny y la Reforma Gregoriana». En El románico en Silos. Santo Domingo de Silos: Abadía de Silos, 1990, pp. 19-29. 


\section{2}

JOSÉ ANTONIO CALVO GÓMEZ

RASGOS DE LA REFORMA DEL CLERO EN LA PENÍNSULA IBÉRICA DURANTE EL SIGLO XI

Pastor, Reyna. «Claudio Sánchez Albornoz, historiador, maestro y militante». En Pastor, Reyna (dir.). Sánchez-Albornoz a debate. Homenaje en la Universidad de Valladolid con motivo de su centenario. Valladolid: Universidad de Valladolid, 1993, pp. 33-44.

Peñalva Gil, Jesús. «Las iglesias patrimoniales en la Castilla medieval. La iglesia parroquial de San Nicolás de Burgos: institución, ordenanzas y regla de 1408». Anuario de Estudios Medievales, 2008, vol. 38/1, pp. 301-366.

Rivera, Juan Francisco. "Gregorio VII y la liturgia mozárabe». Revista Española de Teología, 1942, vol. 2, pp. 3-33.

Rivera, Juan Francisco. "La controversia adopcionista del siglo viII y la ortodoxia de la liturgia mozárabe». Ephemerides Liturgicae, 1933, vol. 47, pp. 506-536.

RodríGuez GiL, Magdalena. «Consideraciones sobre una antigua polémica: las iglesias propias». Cuadernos de Historia del Derecho, 1999, vol. 6, pp. 247-272.

Rodríguez-Picavea Matilla, Enrique. La Corona de Aragón en la Edad Media. Tres Cantos (Madrid): Akal: 1999.

Säвекоw, Gerhard. Die päpstlichen Legationen nach Spanien und Portugal bis zum Ausgang des XII. Jahrhunderts. Berlin: Emil Eberring, 1931.

Sánchez-Albornoz, Claudio. Despoblación y repoblación del valle del Duero, Buenos Aires: Instituto de Historia de España, 1966.

Sánchez-Albornoz, Claudio. España, un enigma histórico. Buenos Aires: Editorial Sudamericana, 1956.

Serrano, Luciano. El obispado de Burgos y Castilla primitiva desde el siglo v al XIII. Madrid: Instituto de Valencia de don Juan, 1935-1936, 3 vols.

SтUтz, Ulrich. Ausgewählte Kapitel aus der Geschichte der Eigenkirche und ihres Rechtes. Weimar: Verlag Hermann Böhlaus Nachfolger, 1937.

STUTz, Ulrich. Die Eigenkirche: als Elements des Mittlelalterlich-germanischen Kirchenrechts. Darmstadt: Wissenschaftliche Buchgesellschaft, 1955.

Tejada y Ramiro, Juan. Colección de cánones y de todos los concilios de la Iglesia de España y de América. Vol. 3 (811-1429). Madrid: Santa Coloma y Peńa, 1861.

Torres López, Manuel. «El origen del sistema de las "iglesias propias"». Anuario de Hstoria del Derecho Español, 1928, vol. 5, pp. 83-217.

Torres López, Manuel. «La doctrina de las "iglesias propias" en los autores españoles». Anuario de Historia del Derecho Español, 1925, vol. 2, pp. 402-461.

Toshiнiro Aвe, J. «La Reforma Gregoriana y Catalunya. Las relaciones entre la Iglesia y el poder secular, siglos XI y XII. De Ramón Berenguer I a Ramón Berenguer III». Acta Historica et Archaeologica Mediaevalia, 2006-2007, vol. 27-28, pp. 9-36.

Vayreda I Olivas, Pere. El priorat de Lladó i les seves filials. Barcelona: Imprenta Giro, 1931.

Villanueva, Jaime. Viage literario a las iglesias de España. Madrid: Real Academia de la Historia, 1850, vol. XIII, pp. 261-264.

Vives, José. Concilios visigóticosos e hispano-romanos. Madrid: Instituto Enrique Flórez, 1963.

Vizuete Mendoza, José Carlos. «La Reforma Gregoriana en Castilla a través de las disposiciones conciliares». En Estudios sobre Alfonso VI y la reconquista de Toledo. Toledo: Instituto de Estudios Visigóticos-Mozárabes, 1988, vol. 2, pp. 321-335. 